\title{
THE SUBFAMILY CANDONINAE (CRUSTACEA, OSTRACODA) IN THE WEST INDIES
}

\author{
by \\ NICO W. BROODBAKKER \\ Institute of Taxonomic Zoology, University of Amsterdam, \\ P.O. Box 20125, 1000 HC Amsterdam, The Netherlands
}

\section{SUMMARY}

Nine new species, two new genera, and two new subgenera of the subfamily Candoninae are described, viz.: a species of the genus Candonopsis, C. hummelincki, probably epigean, with a wide distribution; two new species of the genus Pseudocandona, both elongate in shape, Ps. geratsi, interstitial, in several states of Venezuela, and Ps. antilliana, epigean, widespread throughout the Antillean Islands, including Cuba, Jamaica and Hispaniola; and two species of Pseudocandona with less elongate, reticulated carapaces and a straight dorsal margin, viz. Ps. caribbeana, interstitial, in brooks and small rivers in Jamaica and Venezuela, and Ps. cubensis, troglobitic, found in cave waters in Cuba.

A new hypogean genus of Candoninae, Caribecandona, is described, and divided into two subgenera, one endemic to Cuba (Cubacandona n. subgen., type-species Candonopsis cubensis Danielopol, 1978), and one endemic to Hispaniola (Caribecandona n. subgen., with three new species: $C$. trapezoidea, $C$. auricularia and $C$. ansa).

Another new hypogean genus, Danielocandona, with one new species, $D$. lieshoutae, was discovered in a well in Calabozo (Venezuela, Estado Guárico).

The two new genera, with their trapezoidal carapaces, seem to be relicts of an old tertiary fauna, which did not survive in epigean waters, but only in hypogean habitats in the larger islands Hispaniola and Cuba, which are probably fragments of an old continental plate, and in the mainland of Venezuela. On the sampled smaller islands of the West Indies no hypogean freshwater Ostracoda seem to have evolved. This probably, means that these islands are much younger, and could not recrute any hypogean species from the old Candoninae stock, the ancestral forms being by then probably extinct.

\section{RÉSUMÉ}

On décrit neuf espèces nouvelles, deux genres et deux sous-genres nouveaux, appartenant à la sous-famille Can-

*) Report 33 is published in the same issue of this journal. doninae. Il s'agit: d'une espèce probablement épigée et à large distribution, Candonopsis hummelincki; de deux espèces du genre Pseudocandona, les deux de forme allongée (Ps. geratsi, espèce interstitielle connue de plusieurs états de Venezuela, et Ps. antilliana, espèce épigée largement distribuée aux Antilles, y compris Cuba, la Jamaïque et Hispaniola); de deux espèces de Pseudocandona à carapace moins allongée, réticulée et à bord dorsal droit ( $P$ s. caribbeana, espèce interstitielle de ruisseaux et de petites rivières de la Jamaïque et de Venezuela, et $P$ s. cubensis, espèce cavernicole de Cuba).

Un des genres nouveaux décrits est Caribecandona, au sein duquel on reconnaît deux sous-genres. Un de ceux-ci est endémique à Cuba: Cubacandona n. sg., érigé pour Candonopsis cubensis Danielopol, 1978, l'autre étant endémique pour Hispaniola (Haïti): Caribecandona n. sg., avec trois espèces: $C$. trapezoidea, $C$. auricularia et $C$. ansa.

Le second nouveau genre, Danielocandona, avec l'espèce nouvelle $D$. lieshoutae, a été découvert dans un puits à Calabozo (Venezuela, Estado Guárico).

Les deux genres nouveaux, avec leurs carapaces trapézoïdales, semblent être des relictes d'une vieille faune (du Tertiaire), faune n'ayant pas pu survivre dans les eaux épigées, mais uniquement dans des habitats hypogés des deux grands îles Hispaniola et Cuba, qui sont probablement des fragments d'une ancienne plaque continentale, ainsi que dans ceux de la partie continentale de Venezuela. Il semble que les Ostracodes hypogés d'eau douce sont absents des petites îles des Indes Occidentales; ceci montre probablement que ces îles sont beaucoup plus jeunes, n'ayant pas pu recruter des espèces hypogées à partir d'un ancien contingent de Candoninae (les formes potentiellement ancestrales étant probablement éteintes à l'époque où ce recrutement aurait pu se réaliser).

\section{INTRODUCTION}

The main ostracod groups living in fresh water in the southern hemisphere as well as in Central America, are the Cypridinae, Cypridopsinae 
and Cyclocypridinae. The Darwinulidae, Candoninae and Limnocytheridae are poorly represented in this part of the world.

The West Indies present the same type of fauna. Limnocytheridae have not been encountered in the samples, Darwinulidae only sometimes in springs, most often the species Darwinula stevensoni (Brady \& Robertson, 1868). Candoninae were scarcely encountered, mostly in wells and the interstitia of running waters.

The previous studies concerning the Ostracoda of the West Indies dealt with the genera Heterocypris, Hemicypris, and Strandesia (Broodbakker, 1982; 1983a, b, c), all belonging to the subfamily Cypridinae, and common and widespread in this region. Practically all species of this subfamily and of the subfamilies Cypridopsinae (Cyprettinae) and Cyclocypridinae, proved to be epigean. In the present study the Candoninae are treated as a subfamily, consisting of epigean as well as hypogean and partly hypogean genera. The well-known genera Candonopsis and Pseudocandona and two new hypogean genera have been encountered in the West Indies. The genus Candonopsis is represented by one new species which is present on several of the islands and on the mainland of Venezuela. The genus Pseudocandona is represented by four new species, of which two are closely related to already described taxa from the South and North American continents. One of the new genera was found in wells in Cuba and Haiti, while the other new genus was found in a well in Calabozo, Venezuela.

Until now only one hypogean freshwater species of Ostracoda has been described from the West Indies: Candonopsis cubensis Danielopol, 1978, which is now placed in one of the new genera. Another species, Danielopolina orghidani (Danielopol, 1972), was found in an anchihaline habitat in Cuba. This species belongs to the family Thaumatocyprididae Müller, 1906, a family consisting of deep-sea species, except for this one.

Many West Indian islands have been extensively sampled by Dr. P. Wagenaar Hummelinck and the Amsterdam Expeditions to the
West Indian Islands (Prof. Dr. J. H. Stock, Dr. L. Botosaneanu, Dr. S. Weinberg, Ir. J. Notenboom). Furthermore, many stations have been sampled in Cuba by Dr. L. Botosaneanu, Dr. T. Orghidan and Dr. St. Negrea. Nevertheless, only a few species of hypogean freshwater Ostracoda have been found. Practically all these species belong to the subfamily Candoninae. It seems that most other epigean freshwater, marine and brackish-water species were not capable to evolve into freshwater hypogean Ostracoda, with the possible exception of some species of the genus Strandesia and of the subfamily Thalassocypridinae. The latter , species are, however, oculated, and not clearly morphologically adapted to a subterranean way of life.

\section{MATERIAL AND METHODS}

Most of the samples studied have been collected by the Amsterdam Expeditions to the West Indian Islands (1973-1982), and the expeditions of Dr. P. Wagenaar Hummelinck (1936-1973). For further details about the stations sampled, the reader is referred to Stock (1979) and Wagenaar Hummelinck (1940a-b, 1953, 1981). The samples of the Amsterdam Expeditions and of Dr. P. Wagenaar Hummelinck are abbreviated in the sequel as $\mathrm{S}$ and $\mathrm{WH}$, respectively. More information about the samples containing ostracods is provided by Broodbakker (1982). The samples from Cuba have been collected by Dr. L. Botosaneanu in 1969 and 1973, and by Dr. T. Orghidan in 1969 and 1970. Some samples from Venezuela were collected by Dr. T. Orghidan in 1975. The samples taken by Dr. L. Botosaneanu are indicated with a B. One sample from the Cuevas de Bellamar, Matanzas (Cuba) has been collected by Prof. Dr. Cl. Delamare Deboutteville in 1974, another sample from Cuba by Dr. St. Negrea in 1969.

All material is deposited in the Zoölogisch Museum, Amsterdam (ZMA)

Descriptions of chaetotaxy of the limbs are made according to the system of Bródbakker \& Danielopol (1982). Measuring of carapaces was done with a ruler on a sheet of white paper, on which the animals were projected by way of a camera lucida and a Reichert Diapan microscope. Microslides were made according to the method of Danielopol (1982b).

After every description of a genus or species follow some remarks about the ecology, as far as data are available. All species described belong to the subfamily Candoninae Von Daday, 1900, of the family Cyprididae Baird, 1845. 


\section{A NEW SPECIES OF CANDONOPSIS}

\section{Genus Candonopsis Vávra, 1891}

A new diagnosis of this genus is provided by Danielopol (1980a), together with a list of all Candonopsis species described. Klie (1932) divided the genus in three groups according to the presence or absence of medial teeth on one or both of the furcal claws.

The new species from the West Indies has medial teeth on both furcal claws. Other species with such furcal claws are: $C$. solitaria Vávra, 1895 (Zanzibar); C. navicula Von Daday, 1910 (East Africa); and C. tenuis Sars, 1896 (Australia).

\section{Candonopsis hummelincki n. sp.}

(Fig. 1).

Material. - Holotype: ZMA Ost. 150.582, 1 ㅇ. Paratypes: ZMA Ost. 150.583, 2 dissected and 2 undissected females.

Type-locality: S 78/119, Virgin Gorda (British Virgin Islands), open half-natural well near Post Office of Spanish Town $\left(18^{\circ} 26^{\prime} 42^{\prime \prime} \mathrm{N} \mathrm{64^{ \circ }} 26^{\prime} 26^{\prime \prime} \mathrm{W}\right)$; water table at $2 \mathrm{~m}$, water depth $1 \mathrm{~m}$; chlorinity $640 \mathrm{mg} / \mathrm{l}$; Cvetkov net; 24-IV-1978. Accompanying fauna: Polychaeta, Thermosbaenacea, Insecta, and Cypretta sp. (Ostracoda).

Other stations: WH 534, St. Martin, puddle in head of ravine, Colombier Valley $\left(18^{\circ} 04^{\prime} 04^{\prime \prime} \mathrm{N} 63^{\circ} 03^{\prime} 31^{\prime \prime} \mathrm{W}\right)$; dimensions: $1 / 5 \times 1 / 10 \times 1 / 10 \mathrm{~m}$; stagnant, not permanent, made by removing wet mud and leaf decay; bottom rock detritus with mud on chiefly dioritic rock, in narrow ravine of about $5 \mathrm{~m}$ deep; chlorinity $265 \mathrm{mg} / \mathrm{l} ; 20-\mathrm{V}-1949$; 3 specimens.

S 78/171, Vieques, Pozo Preto, open well in village of Monte Santo $\left(18^{\circ} 07^{\prime} 30^{\prime \prime} \mathrm{N} 65^{\circ} 27^{\prime} 00^{\prime \prime} \mathrm{W}\right)$; water depth $0.4 \mathrm{~m}$; Cvetkov net; chlorinity $600 \mathrm{mg} / \mathrm{l} ; 1-\mathrm{V}-1978 ; 3$ specimens. Accompanying fauna: mosquito larvae and Cypretta sp. (Ostracoda).

S 79/539, Haiti, open well of Gérard Gélan in Marin (Croix des Missions, Dépt. de l'Ouest) (18 $36^{\circ} 31^{\prime \prime} \mathrm{N} 72^{\circ}$ $\left.17^{\prime} 31^{\prime \prime} \mathrm{W}\right)$; very primitive, shallow well, water close to the surface; sediment pale; Cvetkov net; chlorinity $310 \mathrm{mg} / \mathrm{l} ; 2$ specimens. Accompanying fauna: Cyclopidae, Thermosbaenacea; Ostracoda: Cypretta sp., Strandesia longula Broodbakker, $1983 \mathrm{c}$.

S $82 / 500$, Venezuela, source transformed into well in "La Luisa", Peninsula de Morocoy, Edo. Falcon (10 $52^{\circ}$ $03^{\prime \prime} \mathrm{N} 68^{\circ} 19^{\prime} 27^{\prime \prime} \mathrm{W}$ ); at the base of a limestone wall near the road; stagnant, under a roof; dimensions: $1.5 \times 0.5$ $\mathrm{m}$; water depth $0.5 \mathrm{~m}$; Cvetkov net; chlorinity $145 \mathrm{mg} / \mathrm{l}$; 28-II-1982; 1 specimen. Accompanying fauna: Tricladida,
Cyclopidae, Anura larvae; Ostracoda: Strandesia venezolana Broodbakker, 1983c, Cypretta sp., Darwinula sp.

S $82 / 522$, Venezuela, hole dug in sandy sediments along the banks of Rio Mitare, about $100 \mathrm{~m}$ downstream of the Nacimiento de Rio Mitare, a large karst spring near Cabure, Sierra de San Luis, Edo. Falcon (11 $08^{\prime} 24^{\prime \prime} \mathrm{N}$ $\left.69^{\circ} 38^{\prime} 38^{\prime \prime} \mathrm{W}\right)$; chlorinity $60 \mathrm{mg} / \mathrm{l} ; 3-\mathrm{III}-1982 ; 4$ specimens. Accompanying fauna: Nematoda, Oligochaeta, Insecta; Ostracoda: Strandesia venezolana, Pseudocandona geratsi $\mathrm{n}$. sp.

S 82/535, Venezuela, hole dug in fine gravel and coarse sand along the banks of a trickle crossing the road, at 2.5 km from Curuao in the direction of Los Caracas, Dto. Federal $\left(10^{\circ} 36^{\prime} 46^{\prime \prime} \mathrm{N} 65^{\circ} 22^{\prime} 04^{\prime \prime} \mathrm{W}\right)$; in the forest; chlorinity $40 \mathrm{mg} / \mathrm{l}$; 6-III-1982; 1 specimen. Accompanying fauna: Nematoda, Oligochaeta, Cyclopidae, Harpacticoidea, Pisidium (Bivalvia), Acarina (hyphorheobiont), Insecta.

S 82/537, Venezuela, hole dug in coarse gravel and sand between large stones, along the banks of a brook crossing the road, at $7.5 \mathrm{~km}$ from Curuao in the direction of Los Caracas $\left(10^{\circ} 36^{\prime} 58^{\prime \prime} \mathrm{N} 66^{\circ} 23^{\prime} 32^{\prime \prime} \mathrm{W}\right)$; width $2 \mathrm{~m}$, current moderate; chlorinity $25 \mathrm{mg} / \mathrm{l} ; 6$ 6-III-1982; 4 specimens. Accompanying fauna: Oligochaeta, Diptera.

$\mathrm{S} 82 / 573$, Venezuela, hole dug in coarse sand and gravel along the banks of Rio Zuata, $2 \mathrm{~km} \mathrm{~N}$. of San Casimiro, Edo. Aragua ( $\left.10^{\circ} 00^{\prime} 12^{\prime \prime} \mathrm{N} 66^{\circ} 59^{\prime} 47^{\prime \prime} \mathrm{W}\right)$; chlorinity 19 $\mathrm{mg} / \mathrm{l} ; 10$-III-1982; 5 specimens. Accompanying fauna: Nematoda, Harpacticoidea, Calabozoa pellucida Van Lieshout, 1983 (Isopoda), Coleoptera; Ostracoda: Strandesia venezolana, Pseudocandona geratsi $\mathrm{n}$. sp.

Geographical distribution known. Venezuela (Edo. Falcon, Aragua, Sucre and Dto. Federal), St. Martin, Virgin Gorda, Vieques, Haiti.

\section{Description}

Only females of this species have been encountered.

\section{Carapace (figs. 1A-C):}

The carapace is smooth and whitish transparent. Shape and duplicature as in $C$. tenuis. Greatest height behind the middle at twofifths of the length, being $43 \%$ of the length. Greatest width at $50 \%$ of the length, being onethird of the length. Left valve slightly overlapping the right valve. The shape of the valves and the shape of the vestibule in both valves is about the same. Marginal pore canals barely visible, simple, anteroventrally in the right and anterodorsally in the left valve. Both valves 


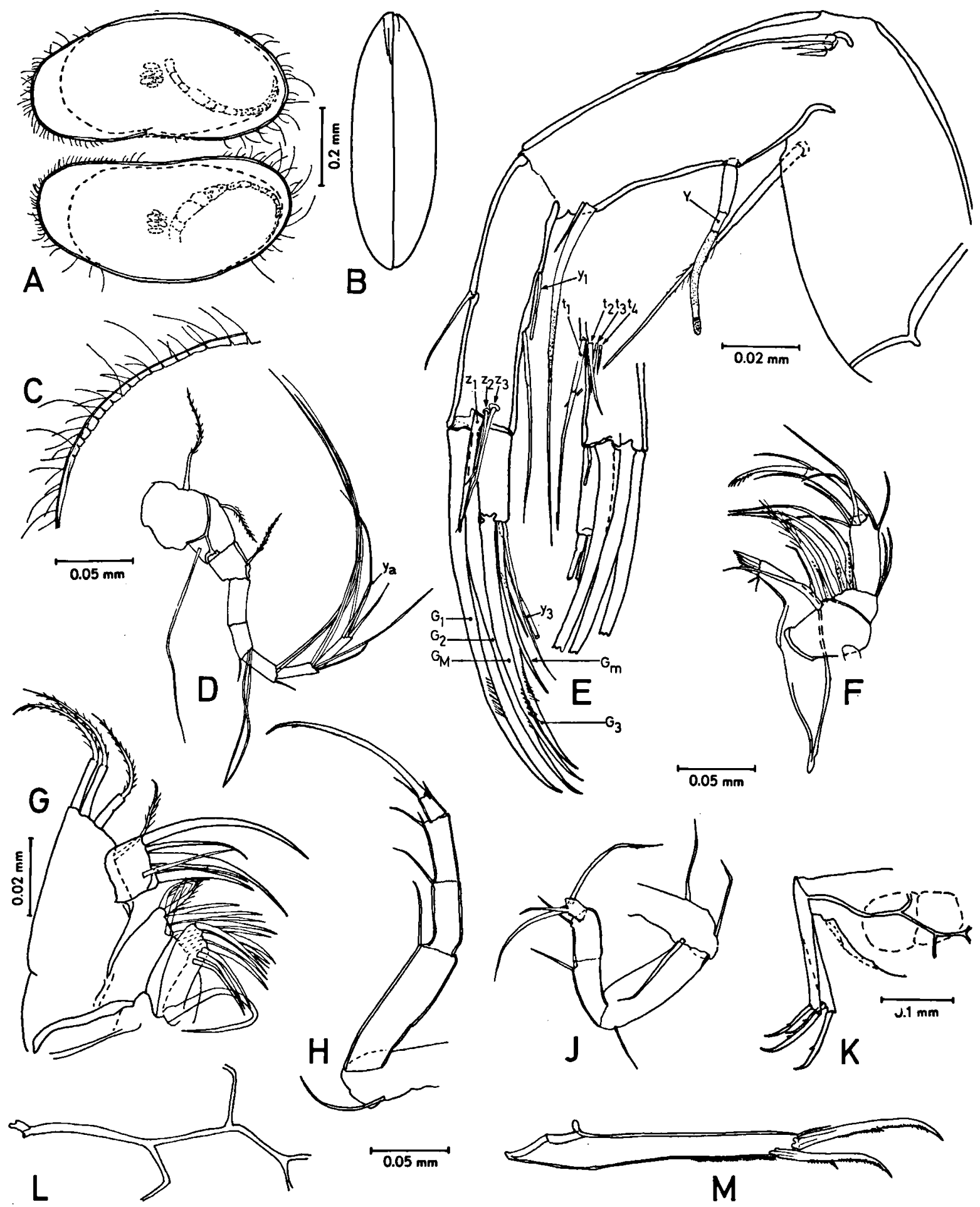

Fig. 1. Candonopsis hummelincki n. sp. (S 78/119, Virgin Gorda; A-D, G, \& no. 2; E-F, H-J, M, \& holotype; K, \& no. 3): A, left and right valve; B, carapace in dorsal view; $C$, detail of anterodorsal part of left valve; $D$, antennule; $E$, second antenna, with detail viewed from other side; F, mandibular palp; G, maxillula; $\mathrm{H}-\mathrm{J}$, first and second thoracopod; K, posterior part of body; L, furcal attachment; M, furca. 
regularly arched. Ventral margin slightly sinuate. Posterior margin somewhat blunter than anterior margin.

Carapace length ranges from $0.65-0.68 \mathrm{~mm}$, at a height of $0.32 \mathrm{~mm}$, in the type-locality. There are no large differences in carapace size between the populations in different islands. In the different samples the carapace length ranges from 0.63-0.70 $\mathrm{mm}$.

Antennule (A1) (fig. 1D):

I: A-1 $l(\mathrm{pl})-1 m(\mathrm{pl}), \mathrm{P}-1 l / \mathrm{II}: \mathrm{A}-1 m(\mathrm{pl}) / \mathrm{IV}: \mathrm{A}-2 l$, P-1s/V: A- $2 l$, P-1s/VI: A- $2 l$, P-1 $l-1 m / \mathrm{VII}: \mathrm{y}_{\mathrm{a}}{ }^{-}$ $2 l-1 m(\mathrm{cs})$.

Aesthetasc $\mathrm{y}_{\mathrm{a}}$ is 1.3 times the length of segment III. The proportional lengths of the segments III to VII are: $1.5: 1: 1.2: 1.2: 1.5$.

Second antenna (A2) (fig. 1E):

Pr: P-1l(pl)/Exo: $1 m(\mathrm{pl})-2 s / \mathrm{E}$ I: P-Y $-1 m(\mathrm{pa})-$ $1 s / \mathrm{E}(\mathrm{II}+\mathrm{III}): \quad \mathrm{A}-1 s, \quad \mathrm{P}-\mathrm{y}_{1}-1 m\left(\mathrm{t}_{1}\right)-3 s\left(\mathrm{t}_{2-4}\right), \quad \mathrm{D}-$ $1 s\left(\operatorname{cs:}: \mathrm{z}_{1}\right)-2 s\left(\mathrm{z}_{2}, \quad 3\right)-\mathrm{y}_{2}-3 l \quad\left(\mathrm{G}_{1}, \quad 2, \quad 3: 1 \mathrm{ser}\right) / \mathrm{E} \quad \mathrm{IV}$ : $\mathrm{D}-\mathrm{y}_{3}-2 s-1 m\left(\mathrm{G}_{\mathrm{m}}: \mathrm{cs}\right)-1 m\left(\mathrm{G}_{\mathrm{M}}: 1\right.$ ser $)$.

The aesthetasc $\mathrm{Y}$ is not strongly developed. Seta $z_{1}$ is transformed in a clawlike seta, and $G_{m}$ is slender and only slightly longer than the longest seta of E IV. $\mathrm{G}_{2}$ is well developed and long.

Mandibular palp (Mdp) (fig. 1F):

I: In- $1 m\left(\mathrm{~S}_{1}: \mathrm{pu}\right)-1 s\left(\mathrm{~S}_{2}: \mathrm{pu}\right)-1 m-\alpha / \mathrm{II}$ : In-3l(pu)$1 s(\mathrm{pu})-\beta(\mathrm{pu}), \mathrm{Ex}-2 s / \mathrm{III}:$ In-1 $m-2 s, \mathrm{Ex}-1 m-1 s / \mathrm{IV}$ : $1 m$ (1 ser)-2s.

The mandibular palp is very elongate, as in the Candonopsis kingsleyi (Brady \& Robertson, 1870) group of species. E III is three and E IV is about seven times as long as wide. Both segments have the same length. Seta $\alpha$ is twice as long as seta $\beta$.

Maxillula (Mxu) (fig. 1G):

Mxup I: $\operatorname{Ex}-3 l(\mathrm{pu})-1 m(\mathrm{pu}) / \mathrm{Mxup}$ II: D-2l(cs)$1 \mathrm{~m}(\mathrm{cs})-3 \mathrm{~m} / \mathrm{Mastic} \mathrm{I}: \mathrm{In}-1 \mathrm{l}, \mathrm{D}-12 \mathrm{~m}($ ?)/Mastic II: D-8m(?)/Mastic III: In- $1 m$, D-2m(cs)-3s(pu)$5 m(?)$.

There is only one seta at the interior of the first masticatory process, as in $C$. boui Danielopol, 1978.
Maxilla (Max):

Pr: A-2s(a), In-1m(b:pu)-1s/Mastic: D-12s/ Exo: $3 s(\mathrm{pu}) / \mathrm{E}: \mathrm{D}-3 s$.

First thoracopod (T 1) (fig. 1H):

Pr: A-1m/E I: A-1s/E II: A-1s/E III: A-2s/E IV: D-2s-1l(G: 1ser).

The proportional lengths of segments and claw are: $5.5: 2.7: 2.6: 1: 7.0$.

The distal claw is 2.6 times the length of E II.

Second thoracopod (T 2) (fig. 1J):

Pr: Ex-2m, In-1 $m /$ E I: P-1s/E II: P-1s/E III: P-1s/E IV: D-1s(pl)-1 $m$ (ser)-1l(pu).

The proportional lengths of E I-IV are: 4.5: 2.3: 1.8: 1. The distal setae of E IV are 45, 93 and $108 \%$ of the length of $E \mathrm{I}$, respectively.

Furca (Fu) \& furcal attachment (Fuat) (figs. $1 \mathrm{M}, \mathrm{L})$ :

The posterior side of the furcal ramus $(R)$ is pectinate for about one-third of its length. The distal claws are pectinate with two rows of teeth, separated by a stronger tooth. $G_{a} / R=$ $63 \%, \mathrm{G}_{\mathrm{p}} / \mathrm{G}_{\mathrm{a}}=81 \%, \mathrm{~s}_{\mathrm{a}} / \mathrm{G}_{\mathrm{a}}=21 \%$.

The furcal attachment is of the Candonopsis type (Rome, 1969).

Copulatory organs (fig. 1K):

The female copulatory organ has no special characters, the posterior side of the organ is flattened.

Taxonomic remarks. - C. falklandica Vávra, 1898, C. anisitsi Von Daday, 1905, and C. columbiensis (Méhes, 1913), all from South America, are not of the type with medial stronger teeth on the furcal claws. $C$. brasiliensis Sars, 1901, from Brazil has a different carapace shape. Sars (1901) did not indicate the type of furca of this species, nor any other internal character.

C. sp. (not kingsleyt), encountered by Tressler (1941) in Bromeliads in Puerto Rico is another species (Danielopol, 1982c).

The furca of $C$. hummelincki is of the $C$. tenuis group type, but the mandibular palp has extremely long segments, like in the $C$. kingsleyi 
group. According to Sars (1896), C. tenuis has the same internal characters as $C$. kingsleyi, except for the furca.

Etymology. - The species is named in honour of Dr. P. Wagenaar Hummelinck, in recognition of his intensive investigations of the Caribbean islands, during which many ostracod samples used for our studies were obtained.

Ecology. - The fact that Sars (1901) raised two specimens of $C$. brasiliensis from dried mud seems to indicate that the genus Candonopsis can have resistant eggs, like many Cypridinae. Another possibility is that the two specimens were in a torpid state in the mud (Delorme \& Donald, 1969). From Sars's description of $C$. tenuis it remains unclear if he obtained his specimens from dried mud, or from ostracod samples, or both.

Samples containing $C$. hummelincki were scarce. In all samples only a few specimens were present. The fact that the species was found on the islands of Hispaniola, Vieques, Virgin Gorda and St. Martin, as well as on the mainland of Venezuela, suggests a much wider distribution.

The species lives in the bottom substrates of running waters as well as in small shallow open wells. It was present in only one sample collected by Dr. P. Wagenaar Hummelinck, in a small puddle in a ravine on St. Martin. The species was accompanied by several other species of ostracods, but mostly by Cypretta sp. It was found at chlorinities up to $640 \mathrm{mg} / \mathrm{l}$. The wide distribution and the occurrence in the puddle on St. Martin, suggest that it is an epigean species.

\section{FOUR NEW SPECIES OF PSEUDOCANDONA}

Genus Pseudocandona Kaufmann, 1900

The genus Pseudocandona was described very concisely by Kaufmann (1900) and was characterized by the absence of sexually dimorphic characters in the second antenna. The type-species of the genus is Candona insculpta
Müller, 1899. However, related species have been found which display sexually dimorphic characters in the second antenna.

Triebel (1963) placed the groups rostrata and compressa of the genus Candona Baird, 1845, in Pseudocandona, which he considered to be a subgenus. Petkovski (1969) gave the two groups the status of genus, because of the structure of the copulatory organs.

Within the genus Pseudocandona four main groups can be recognized:

(1) the rostrata group, which has $2+3$ setae at the interior side of the second segment of the mandibular palp (Mdp: II: In);

(2) the compressa group, which has $2+4$ or $2+5$ setae at this place;

(3) the eremita group, like rostrata with the $2+3$ configuration, but with a triangular carapace (Danielopol, 1982a);

(4) the Lake Baikal group of species, or baikalensis group, which has a round instead of a funnel-shaped structure at the proximal side of the Zenker's organ (Danielopol, 1978: 133).

Practically all groups and their main characters are discussed in Danielopol (1978, 1982a).

The four new species described in this study belong to the rostrata group, according to the chaetotaxy of the mandibular palp.

Pseudocandona geratsi n. sp.

(Figs. 2, 3)

Material. - One female holotype, one male allotype, one female paratype, and fragments of some other female specimens, partly dissected on one slide (ZMA Ost. 150.786).

Type-locality: Guarapiche, Venezuela (Edo. Sucre), hole dug in the bank of a river $\left(10^{\circ} 31^{\prime} \mathrm{N} 63^{\circ} 24^{\prime} \mathrm{W}\right)$; 17-V-1975; coll. Dr. T. Orghidan. Accompanying ostracod species: Candonopsis hummelincki, Darwinula sp. and Cypridopsis aff. vidua (Müller, 1776).

Other stations (all in Venezuela): S 82/522, hole dug in sandy sediments along the banks of Rio Mitare, about 100 m downstream of the Nacimiento de Rio Mitare, a large karst spring near Cabure, Sierra de San Luis, Edo. Falcon $\left(11^{\circ} 08^{\prime} 24^{\prime \prime} \mathrm{N} 69^{\circ} 38^{\prime} 38^{\prime \prime} \mathrm{W}\right)$; chlorinity $60 \mathrm{mg} / \mathrm{l} ; 4$ females and 2 juveniles. Accompanying fauna: Nematoda, Oligochaeta, Insecta; Ostracoda: Strandesia venezolana, Candonopsis hummelincki. 
S 82/530, spring of Cipare, about $3 \mathrm{~km} \mathrm{~N}$. of Guaibacoa, Edo. Falcon $\left(11^{\circ} 24^{\prime} 51^{\prime \prime} \mathrm{N} 69^{\circ} 27^{\prime} 22^{\prime \prime} \mathrm{W}\right)$; modified spring, water collected in a covered concrete basin, depth $0.5 \mathrm{~m}$; Cvetkov net; sandy bottom; chlorinity $330 \mathrm{mg} / 1$; 5-III-1982; 1 juvenile and a carapace. Accompanying fauna: Oligochaeta, Gastropoda, Chironomidae; Ostracoda: Cypretta sp.

S 82/531, hole dug in a bank of gravel and coarse sand with large boulders, in the middle of the fast running river Rio Acurigua, in village Acurigua, Sierra de San Luis, Edo. Falcon (11 $18^{\prime} 54^{\prime \prime} \mathrm{N} 69^{\circ} 28^{\prime} 48^{\prime \prime} \mathrm{W}$ ); width $5 \mathrm{~m}$, water depth $0.5 \mathrm{~m}$; chlorinity $80 \mathrm{mg} / \mathrm{l} ; 5-\mathrm{III}-1982 ; 1$ female. Accompanying fauna: Oligochaeta, Insecta; Ostracoda: Ps. caribbeana n. sp.

$\mathrm{S} 82 / 573$, hole dug in coarse sand and gravel along the banks of Rio Zuata, $2 \mathrm{~km} \mathrm{~N}$. of San Casimiro, Edo. Aragua $\left(10^{\circ} 00^{\prime} 12^{\prime \prime} \mathrm{N} 66^{\circ} 59^{\prime} 47^{\prime \prime} \mathrm{W}\right)$; chlorinity $20 \mathrm{mg} / \mathrm{l}$; 10-III-1982; 1 female. Accompanying fauna: Nematoda, Harpacticoidea, Calabozoa pellucida (Isopoda), Coleoptera; Ostracoda: Candonopsis hummelincki, Strandesia venezolana.

Geographical distribution known. Venezuela (Edo. Falcon, Sucre, Aragua).

\section{Description}

Only one male of this species has been encountered.

Carapace (figs. 2A-E):

In dorsal view greatest width at $50 \%$ of the length, being one-third of the length. Left valve slightly larger than and overlapping the right valve. Greatest height behind the middle at two-thirds of the length, length/height ratio about 2.

The shape of left and right valves is nearly the same. There is no clear dimorphism in the shape of the valves between males and females. Both valves regularly arched, oblong reniform in shape. The dorsal margin passes smoothly in the rounded anterior and posterior margins. Ventral margin slightly sinuate. Duplicature much wider anteriorly than posteriorly. Marginal pore canals indistinct. Valves sparsely hairy. Muscle scars as typical of the Candoninae.

The male allotype has a length of $0.77 \mathrm{~mm}$ and a height of $0.38 \mathrm{~mm}$. The females from the type-locality are deformed because of decalcification, but they were 0.64 and 0.68 $\mathrm{mm}$ in length. The females from the other localities range from $0.63-0.65 \mathrm{~mm}$ in length, except for the female from $S 82 / 531$, which is $0.76 \mathrm{~mm}$ long.

Antennule (A 1) (fig. 2F):

I: A-2l(pl), P-2l/II: A- $1 m(\mathrm{pl}) / \mathrm{III}: \quad \mathrm{A}-1 l / \mathrm{IV}$ :

A- $2 l$, P $-1 m / \mathrm{V}:$ A $-2 l$, P $-1 m / \mathrm{VI}:$ A $-3 l-1 m / \mathrm{VII}$ : D-3l-ya.

All setae seem to be long, but this is because segment III is very short. The proportional lengths of the segments III to VII are: 1: 1.3: 1.4: 1.6: 1.5 .

Second antenna (A 2) (figs. 2G-H):

Pr: P-1 $1 m(\mathrm{pu}) /$ Exo: $1 m-1 s /$ E I: P-Y $-1 m(\mathrm{pl})-1 s /$ Q : $\quad \mathrm{E}(\mathrm{II}+\mathrm{III}): \quad \mathrm{A}-1 s(\mathrm{pl}), \quad \mathrm{P}-\mathrm{y}_{1}-2 m\left(\mathrm{t}_{1}, 2: \mathrm{pl}\right)-$ $2 s\left(\mathrm{t}_{3}, 4\right), \mathrm{D}-\mathrm{y}_{2}-3 s\left(\mathrm{z}_{1}, 2,3\right)-1 l\left(\mathrm{G}_{1}: \mathrm{ser}\right)-1 s\left(\mathrm{G}_{2}: \mathrm{ser}\right)-$ $1 m\left(\mathrm{G}_{3}: \mathrm{ser}\right) / \mathrm{E}$ IV: D-2m( $\left.\mathrm{G}_{\mathrm{M}, \mathrm{m}}: \mathrm{ser}\right)-1 m-1 s-\mathrm{y}_{3}$. O*: E II: P-y ${ }_{1}-1 m\left(\mathrm{t}_{1}\right), \mathrm{A}-1 s-1 s\left(\mathrm{t}_{4}\right), \mathrm{Ex}-1 m\left(\mathrm{t}_{2}\right)-$ $1 s\left(\mathrm{t}_{3}\right) / \mathrm{E}$ III: $\mathrm{D}(\mathrm{Ex})-1 s\left(\mathrm{z}_{1}\right), \mathrm{D}(\mathrm{In})-1 s\left(\mathrm{z}_{2}\right)-1 m\left(\mathrm{z}_{3}\right)$, D- $2 m\left(\mathrm{G}_{2}, 3\right)-1 l\left(\mathrm{G}_{1}\right) / \mathrm{E}$ IV: $\mathrm{D}-2 m\left(\mathrm{G}_{\mathrm{M}, \mathrm{m}}\right)-1 m$ $1 s-y_{3}$.

The chaetotaxy of $\mathrm{t}$ and $\mathrm{z}$ setae in the male is the same as in Ps. serbani Danielopol, 1982b (see Broodbakker \& Danielopol, 1982). $\mathrm{G}_{2}$ is slender, $t_{2}$ and $t_{3}$ are strongly developed "male" setae. Setae $z_{2}$ and $z_{3}$ have moved to the interior side of $A 2$, and $z_{1}$ has moved somewhat posteriorly. The male has a foursegmented endopodite, while in the female the second and third segments are fused, like in most female Candoninae, which means that this species is not a Pseudocandona species sensu Kaufmann. The other limbs have the same chaetotaxy in males and females.

Mandibular palp (Mdp) (fig. 2J):

I: $\quad$ In- $1 l-1 l\left(\mathrm{~S}_{1}: \mathrm{pu}\right)-1 s\left(\mathrm{~S}_{2}: \mathrm{pu}\right)-\alpha / \mathrm{II}: \quad$ In-3l(pu)$1 m(\mathrm{pu})-\beta, \quad \mathbf{E x}-2 m / \mathrm{III}$ : In-1 $m-1 s, \quad \mathrm{Ex}-3 l, \quad \mathrm{~A}-$ $2 l / \mathrm{IV}: \mathrm{D}-1 l(\mathrm{cs}: \mathrm{pu})-3 m$.

The $\gamma$ seta is not special in this species, $\beta$ does not seem to be plumose.

Maxillula (Mxu) (fig. 2L):

Mxup I: $\quad \mathrm{Ex}-3 l(\mathrm{pu})-1 m(\mathrm{pu}) / \mathrm{II}: \quad \mathrm{D}-2 m(\mathrm{cs})-$ $2 m(\mathrm{pu})-2 m /$ Mastic I: In-1l-1m(pu), D- $1 l$ $10 m($ ?)/2: D-8m(?)/3: In-1 $m$, D-2m(cs)-8m(?). 

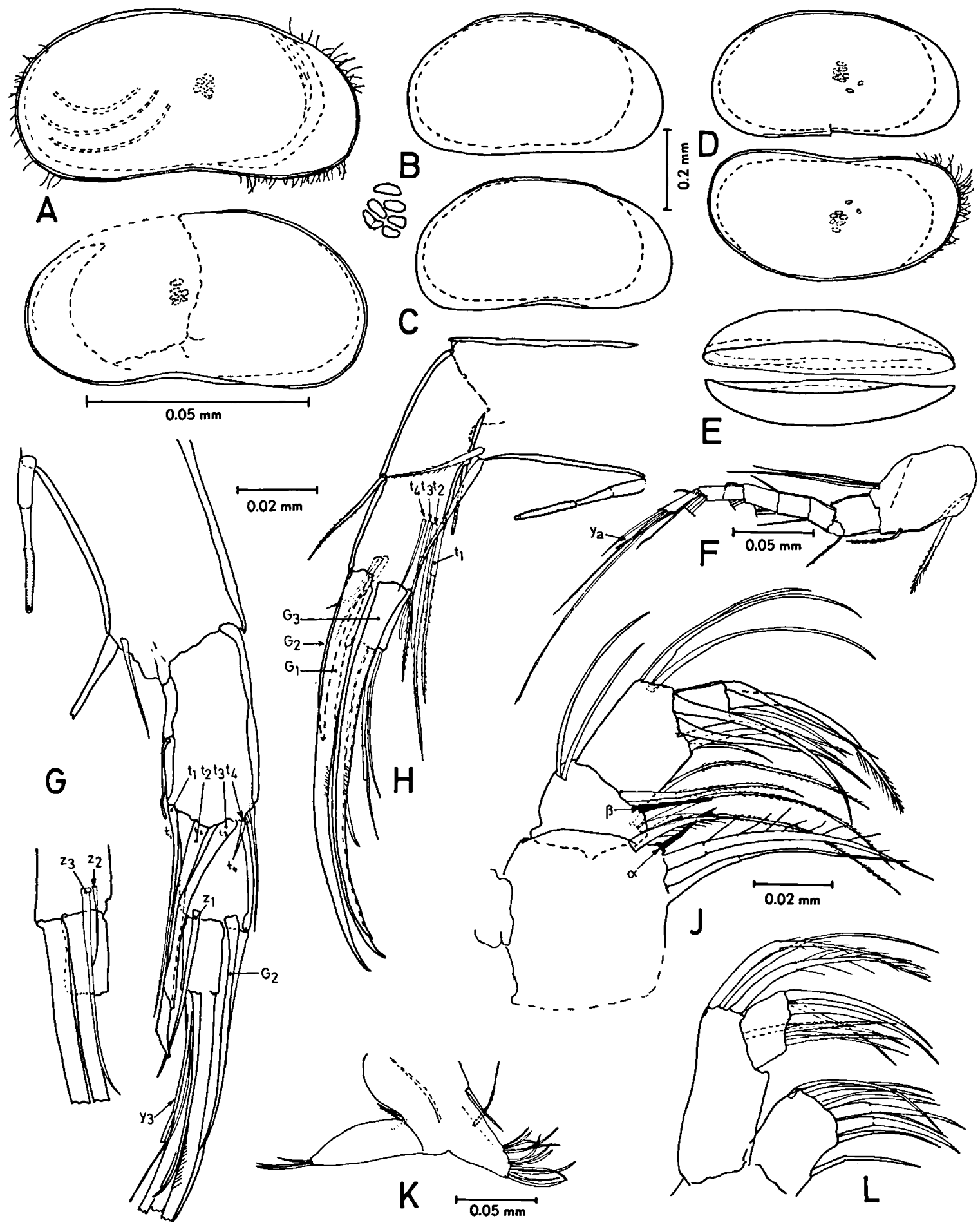

Fig. 2. Pseudocandona geratsi n. sp. (A-B, G, Guarapiche, Venezuela, Edo. Sucre: A, G, o allotype; B, $९$ holotype; C, S 82/573, Venezuela, Edo. Aragua, $९$; D-F, H-L, S 82/522, Venezuela, Edo. Falcon, $\bigcirc$ no. 1); A, D, right and left valve, E, in dorsal view; B, carapace in lateral view; C, right valve, with muscle prints; F, antennule; G-H, details of second antennae; J, mandibular palp; K, maxilla; L, maxillula. 

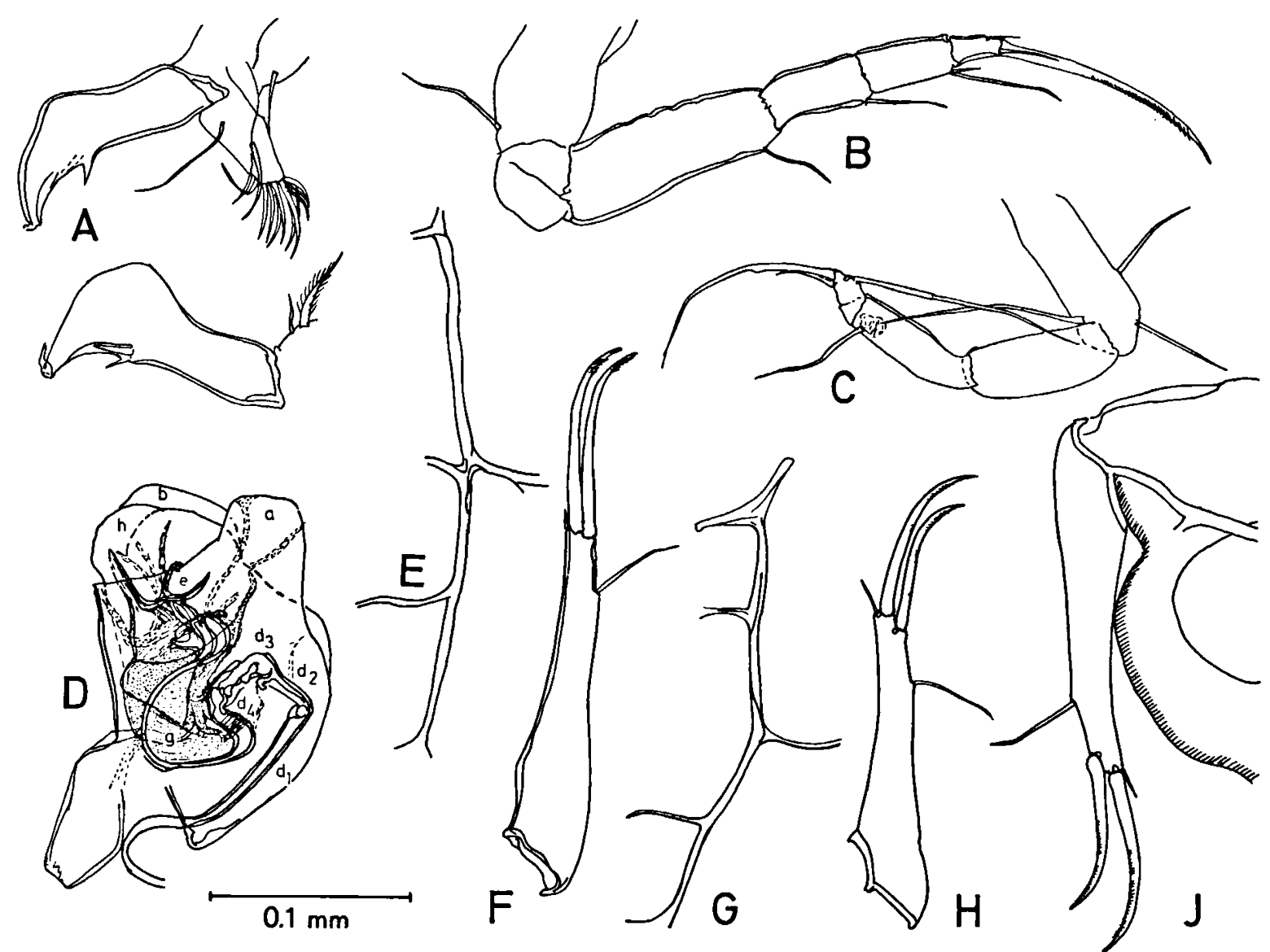

Fig. 3. Pseudocandona geratsi n. sp. (A-H, Guarapiche, Venezuela, Edo. Sucre: A-F, $\sigma$ allotype; G, $\$$ holotype; H, $\$$ no. 2; J, S 82/531, Venezuela, Edo. Falcon, \&): A, maxillae; B-C, first and second thoracopod; D, hemipenis (for explanation see text); E, G, furcal attachments; F, H, furcas; J, posterior part of body.

The chelate setae of the third masticatory process do not seem to be serrate.

Maxilla (Max) (figs. 2K, 3A):

Pr: A-1s(a), In-2s(b, d)/Mastic: D-12s(?)/Exo: P-1s(pl)-1s/E( \& ): D-3s.

The maxilla has two small exopodal setae of which one is plumose (fig. 3A, below). The male endopodites are transformed into claws, of which the right one is more elongated. They are of the same type as in most other Pseudocandona species.

First thoracopod (T 1) (fig. 3B):

Pr: A-1 $m /$ E I: A-1s/E II: A-1s/E III: A- $1 m-1 s /$ E IV: A-1s, P-1s, D-1l(G:ser).

The proportional lengths of segments and claw are: $4.6: 2.1: 1.9: 1: 5.1$. The terminal claw is 2.4 times the length of E II and 1.1 times the length of $\mathrm{E} I$.

Second thoracopod (T 2) (fig. 3C):

Pr: Ex-2m, In-1 $l / \mathrm{E}(\mathrm{II}+\mathrm{III}):$ P- $1 m / \mathrm{E}$ IV: D$1 l(\mathrm{ser})-1 l(\mathrm{pl})-1 s$.

All setae are plumed. The second and third endopodite segments are fused.

Furca (Fu) \& furcal attachment (Fuat) (figs. 3E-H):

There seems to be some sexual dimorphism. In the male, $G_{p}$ has the same length as $G_{a}$, while in the female $G_{p} / G_{a}$ is $83 \%$. Seta $s_{a}$ seems to be somewhat shorter in the male $\left(\mathrm{s}_{\mathrm{a}} / \mathrm{G}_{\mathrm{a}}\right.$ is $10 \%$ in the male and $20 \%$ in the female). $G_{a} / R$ is $65 \%$ 
in both male and female. Because of the shorter $G_{p}$ in the female, $s_{p} / G_{p}$ is $48 \%$ in females and $60 \%$ in males.

One of the branches of the furcal attachment has moved anteriorly in the male, when compared with the female furcal attachment (figs. $3 \mathrm{E}, \mathrm{G})$.

Copulatory organs (figs. 3D, J):

The female copulatory organ is rounded posteriorly and has no other special characteristics (fig. 3J).

The Zenker's organs of the male have seven whorls of spines, like most other Candoninae.

The terminology of Danielopol $(1969,1982 b)$ is used for the internal structure of the hemipenis. The shape of the hemipenis is of the typical Pseudocandona type, with all distal lobes pointing backwards, a blunted lobe ' $a$ ' and more rounded ' $b$ ' and ' $h$ ' lobes. The part ' $M$ ' $(\mathrm{g})$ is very difficult to recognize, it is only weakly sclerotized. Several sclerotized structures are visible in the distal part of the hemipenis, which could belong to the bursa copulatrix (e). The parts ' $d_{1-4}$ ' of the labyrinth are all clearly visible.

Taxonomic remarks. - The species shows close affinities with Ps. annae (Méhes, 1913) from Colombia. However, the carapace shape and the male copulatory organ are different. The male Pseudocandona described by Furtos (1936) as Ps. annae must be another species according to her drawings. It is probably closely related to Ps. geratsi, Ps. annae, and even closer to Ps. antilliana n. sp., which is described next. Ps. geratsi also shows some affinities with Ps. elliptica Furtos, 1933, from Ohio.

Etymology. - The species is named in honour of Drs. A. G. M. Gerats, a true friend and promising plant geneticist.

Ecology. - Only a few samples containing this species were found. These were practically all from coarse sediments along the banks of small streams and rivers, with chlorinities up to 330 $\mathrm{mg} / \mathrm{l}$. The morphological characteristics do not indicate interstitial adaptation, but according to the definition of Danielopol (1980b), a species is supposed to be hypogean or "true interstitial" until proof of the contrary is obtained.

\section{Pseudocandona antilliana $\mathrm{n}$. sp.}

(Figs. 4, 5)

Material. - Holotype: ZMA Ost. 150.588, 1 female. Paratypes: ZMA Ost. 150.589, 1 dissected and about 100 undissected females.

Type-locality: S 79/549, Haiti, well of Emile Magloire at Ti Mouillage, about $40-50 \mathrm{~m}$ from the littoral, Dépt. du Sud-Est $\left(18^{\circ} 14^{\prime} 01^{\prime \prime} \mathrm{N} 72^{\circ} 22^{\prime} 26^{\prime \prime} \mathrm{W}\right)$; water table at $3 \mathrm{~m}$, water depth $1 \mathrm{~m}$; chlorinity $70 \mathrm{mg} / \mathrm{l}$; Cvetkov net; 13-XI-1979. Accompanying fauna: Cyclopidae, Gastropoda, Acarina, Insecta; Ostracoda: Strandesia longula, Cypretta sp.

Only in one sample a male of this species was encountered, which was used for the description: B 69/44, Cuba, Cueva del Agua, in a place called "El Veral" (Peninsula de Guanahacabibes, Prov. Pinar del Rio), close to the littoral $\left(21^{\circ} 57^{\prime} \mathrm{N} 84^{\circ} 31^{\prime} \mathrm{W}\right)$; small cave pool situated at $4.5 \mathrm{~m}$ below the bottom of the cave; limestone bottom with stones and some fine sediment; fresh clear water; pH 8; temp. $23.1^{\circ} \mathrm{C}$; 3-VI-1969. Coll. St. Negrea. Only one male and a carapace, no other Ostracoda.

Other stations: S 82/519, Venezuela, Manantial "Quevey" in La Peña (near San Luis), Sierra de San Luis, Edo. Falcon $\left(11^{\circ} 07^{\prime} 22^{\prime \prime} \mathrm{N} 69^{\circ} 45^{\prime} 07^{\prime \prime} \mathrm{W}\right)$; spring in the mostly dry bed of a rivulet with large boulders; muddy, much detritus; hand net; chlorinity $205 \mathrm{mg} / \mathrm{l}$; 3-III-1982; 4 specimens. Accompanying fauna: Nematoda, Oligochaeta, Tricladida, Insecta; Ostracoda: Strandesia venezolana.

S $82 / 523$, Venezuela, hole dug in fine red clayish sediment and gravel, between large boulders along the banks of Rio Hueque, where it crosses the road from Cabure to Pueblo Nuevo, Sierra de San Luis, Edo. Falcon $\left(11^{\circ} 08^{\prime}\right.$ $45^{\prime \prime} \mathrm{N} 69^{\circ} 31^{\prime} 26^{\prime \prime} \mathrm{W}$ ); mountain river; chlorinity less than $1 \mathrm{mg} / \mathrm{l}$; 4-III-1982; 1 specimen. Accompanying fauna: Nematoda, Gastropoda, Diptera.

WH 72, Curaçao, Boca di Leeuw, Hato $\left(12^{\circ} 11^{\prime} 05^{\prime \prime} \mathrm{N}\right.$ $\left.68^{\circ} 56^{\prime} 54^{\prime \prime} \mathrm{W}\right)$; slowly flowing, permanent, natural, builtin spring; dimensions: $2 \times 1.5 \times 0.3 \mathrm{~m}$; in corallimestone and some shale, with clayish mud and brickwork; no vegetation; clear water; chlorinity $30 \mathrm{mg} / \mathrm{l}$; sampled at 13-X-1936 and 29-VIII-1949; 1 and 3 specimens. Accompanied by Danwinula stevensoni (Brady \& Robertson, 1870) (Ostracoda).

WH 74, Curaçao, Bron Cajoeda, Hato; spring in small basin of brickwork; permanent; overflowing; in corallimestone and shales; chlorinity $300-1100 \mathrm{mg} / \mathrm{l}$; sampled at 1-X-1936, 5-V-1949 and 27-VIII-1955; 7, 4 and 6 specimens. Accompanied by Darwinula stevensoni (Ostracoda). 
WH 77, Curaçao, Bak Rincón, Hato; probably permanent pools of variable depth, yielded 3 specimens at 11-X-1936, together with Cypridopsis sp. and Darwinula stevensoni. The spring from which this water originates yielded 4 specimens at $15-\mathrm{X}-1967$. The spring is captured in an overflowing cemented cistern on coral-limestone and shale; water depth $1 \mathrm{~m}$; clear water; chlorinity $150 \mathrm{mg} / 1$.

WH 788, Barbados, Ronald Tree's pool, N. of Bellair's Holetown; cemented basin in garden; dimensions: $5 \times 4$ $\times 1 \mathrm{~m}$; crowded with water lilies, Chara, Nelumbo and algae; chlorinity $640 \mathrm{mg} / \mathrm{l}$; 21-II-1964; 25 specimens. Accompanying Ostracoda: Potamocypris sp., Cypridopsis aff. vidua, Stenocypris major (Baird, 1859).

WH 851, Martinique, Rivière Oman, 2 km N. of Anse des Trois Rivières; large pool in almost stagnant rivulet; pasture-like area; very muddy; turbid; chlorinity 2130 $\mathrm{mg} / \mathrm{l} ; 12-\mathrm{VII}-1967 ; 1$ specimen. Accompanying fauna: Decapoda, Heteroptera; Ostracoda: Heterocypris punctata Keyser, 1975 and Cypridopsis sp.

WH $740 A$, La Désirade, muddy pool about $30 \mathrm{~m}$ from Source de Cybèle; dimensions: $1 \times 1 \times 0.2 \mathrm{~m}$; chlorinity $225 \mathrm{mg} / \mathrm{l} ; 24-\mathrm{I}-1964 ; 6$ specimens. Accompanying Ostracoda: Cypridopsis sp.

S 78/43, Antigua, large covered basin with small opening in Parish of St. Paul, S. of Falmouth $\left(17^{\circ} 05^{\prime} 06^{\prime \prime} \mathrm{N}\right.$ $\left.61^{\circ} 44^{\prime} 14^{\prime \prime} \mathrm{W}\right)$; windpump ruined; Cvetkov net; chlorinity $1400 \mathrm{mg} / 1 ; 13-\mathrm{IV}-1978 ; 9$ specimens. Accompanying fauna: Cyclopidae, Phyllopoda, Pyrgophorus (Gastropoda); Ostracoda: Physocypria affinis Klie, 1933.

S 78/44, Antigua, John Hughes well, S. of road ( = Mill Hill), Parish of St. Mary $\left(17^{\circ} 02^{\prime} 37^{\prime \prime} \mathrm{N} 61^{\circ} 49^{\prime} 09^{\prime \prime} \mathrm{W}\right)$; round, diam. $2 \mathrm{~m}$; largely covered; clean water; chlorinity $920 \mathrm{mg} / \mathrm{l}$; 13-IV-1978; 1 specimen. Accompanying fauna: Cyclopidae, Pyrgophorus; Ostracoda: Physocypria affinis, Strandesia sphaeroidea Broodbakker, 1983c.

WH 546, Dog Island, well near N. coast; stagnant, probably permanent; excavated $0.5 \mathrm{~m}$ below surface; dimensions: $2 \times 2 \times$ ? $1 \mathrm{~m}$; in limestone; some mud; clear water; chlorinity $1410 \mathrm{mg} / \mathrm{l} ; 17-\mathrm{VI}-1949 ; 1$ specimen. Accompanying Ostracoda: Darwinula stevensoni.

S 78/107, Anegada, Smith's well in the Settlement $\left(18^{\circ}\right.$ $\left.43^{\prime} 16^{\prime \prime} \mathrm{N} 69^{\circ} 19^{\prime} 03^{\prime \prime} \mathrm{W}\right)$; chlorinity $1160 \mathrm{mg} / \mathrm{l}$; only a valve.

$S 78 / 172$, Vieques, open well behind a house in Monte Santo $\left(18^{\circ} 07^{\prime} 34^{\prime \prime} \mathrm{N} 65^{\circ} 26^{\prime} 55^{\prime \prime} \mathrm{W}\right)$; water table at $0 \mathrm{~m}$, water depth $0.3 \mathrm{~m} ; 1-\mathrm{V}-1978 ; 1$ specimen. Accompanying fauna: Oligochaeta, Cyclopidae; Ostracoda: Cypretta sp.

Samples taken in Haiti: S 78/212, Dépt. du Sud-Est, covered well in Cayes-Jacmel, backyard of house (18 $18^{\prime}$ $54^{\prime \prime} \mathrm{N} 72^{\circ} 23^{\prime} 49^{\prime \prime} \mathrm{W}$ ); diam. $1 \mathrm{~m}$; water table at $7 \mathrm{~m}$, water depth $1 \mathrm{~m}$; Cvetkov net; chlorinity $40 \mathrm{mg} / \mathrm{l}$; 5-V-1978; 2 specimens. Accompanying fauna: Oligochaeta, Cyclopidae, Culicidae, Gastropoda.

S 79/529, Dépt. de l'Ouest, hole dug in gravel and moving sand along the banks of the fast running brook Balisaille, there where it cuts the road Santhier - Croix des Bouquets $\left(18^{\circ} 32^{\prime} 40^{\prime \prime} \mathrm{N} 72^{\circ} 05^{\prime} 37^{\prime \prime} \mathrm{W}\right)$; chlorinity 36 mg/l; 9-XI-1979; 2 specimens. Accompanying fauna: Oligochaeta, Polychaeta, Insecta; Ostracoda: Strandesia stocki Broodbakker, 1983c.

S 79/630, Dépt. de l'Artibonite, Source "Tête Nègre", close to the road from Mirebalais to Lascahobas $\left(18^{\circ} 49^{\prime}\right.$ $40^{\prime \prime} \mathrm{N} 72^{\circ} 05^{\prime} 06^{\prime \prime} \mathrm{W}$ ); four very small limnocrenes, almost stagnant, no exit; chlorinity $23 \mathrm{mg} / \mathrm{l} ; 28-\mathrm{XI}-1979 ; 1$ specimen. Accompanying fauna: Cyclopidae, Insecta, Gastropoda; Ostracoda: Stenocypris major, Strandesia stocki, Cypretta sp.

S 79/638, Dépt. de Grande Anse, well of the corn-mill, in the centre of Jérémie, about $120 \mathrm{~m}$ from the littoral $\left(18^{\circ}\right.$ $\left.39^{\prime} 27^{\prime \prime} \mathrm{N} 74^{\circ} 08^{\prime} 44^{\prime \prime} \mathrm{W}\right)$; narrow; masonry inside; covered; water table at $0.1 \mathrm{~m}$, water depth $1.8 \mathrm{~m}$; chlorinity $250 \mathrm{mg} / \mathrm{l} ; 1-\mathrm{XII}-1979 ; 1$ specimen. Accompanying fauna: Oligochaeta, Cyclopidae, Diptera; Ostracoda: Cypretta sp.

S 79/639, Dépt. de Grande Anse, Berquer well at Jérémie, Paul Emile Jean-Michel street, about $100 \mathrm{~m}$ from the sea $\left(18^{\circ} 38^{\prime} 32^{\prime \prime} \mathrm{N} 74^{\circ} 07^{\prime} 05^{\prime \prime} \mathrm{W}\right)$; masonry inside; open; clean; water table at $4 \mathrm{~m}$, water depth $0.8 \mathrm{~m}$; chlorinity $130 \mathrm{mg} / \mathrm{l} ; 1$-XII-1979; 1 specimen. Accompanying fauna: Oligochaeta, Cyclopidae, hadziid Amphipoda, Insecta, Gastropoda; Ostracoda: Cypretta sp.

S 79/657 Dépt. de Grande Anse, spring at Beaucalin, on the road along the river La Grande Anse $\left(18^{\circ} 35^{\prime} 36^{\prime \prime} \mathrm{N}\right.$ $\left.74^{\circ} 11^{\prime} 57^{\prime \prime} \mathrm{W}\right)$; slight water supply; dug in sand and calcareous gravel; chlorinity $16 \mathrm{mg} / \mathrm{l} ; 5-\mathrm{XII}-1979 ; 3$ specimens. Accompanying fauna: Oligochaeta, Isopoda, Diptera, Pisces.

Samples from Cuba: B 69/1, Cueva Majaes, 20 km S.E. of Santiago de Cuba, Prov. Granma (named Prov. de Oriente until 1975), small cave pools; depth 0.1 to $0.3 \mathrm{~m}$; much guano; 23-III-1969; 6 specimens, accompanied by carapaces of Darwinulidae. Coll. L. Botosaneanu.

Carapaces of the species were found in: B 69/18, Cueva del Fustete, S. side of the Gulf of Guacanayabo, Prov. Granma; B 69/26, Cueva del Aqua and B 69/32, Cueva del Indio, both in the Sierra de Cubitas, Prov. Camagüey; B 69/45, Cueva de Pio Domingo, in the Sierra de Los Organos, Prov. Pinar del Rio; and B 69/26, Cueva de Bellamar, Matanzas, Barrio Guanábana, $1.4 \mathrm{~km} \mathrm{~S}$. of the Gulf of Matanzas, large cave with more than $3 \mathrm{~km}$ of galleries, many cave pools, very small and up to 3-4 m length. Prof. Dr. Cl. Delamare Deboutteville found on 12-III-1973, 13 specimens of the species, and some Darwinulidae, in this cave.

More information about the Cuban caves is provided in Botosaneanu (1970).

Geographical distribution known. Jamaica, Cuba, Haiti, Vieques, Anegada, Antigua, Dog Island, La Désirade, Martinique, Barbados, Curaçao, Venezuela. 


\section{Description}

It is postulated that the species is parthenogenetic in most of its populations, since only one male was found in only one of the many samples containing this species.

Carapace (figs. 4A, 5A-C):

The carapace is smooth and whitish transparent. Hinge adont. Muscle scars as typical of Candoninae. In dorsal view greatest width at $50 \%$ of the length, being about onethird of the length. Left valve larger than and overlapping the right valve. In lateral view greatest height behind the middle at $30 \%$ of the length, being $45 \%$ of the length. In the female the dorsal margin is straight in the medial part and progresses with an angle of $30^{\circ}$ in the anterior margin and with an angle of $45^{\circ}$ in the posterior margin. In the male the dorsal margin is more inclined downward anteriorly, and passes more smoothly in the posterior and anterior margins. Both anterior and posterior margins are rounded. In the female the anterior margin is more blunted and in the male the posterior margin. The ventral margin is slightly sinuate in the left, and somewhat more sinuate in the right valve. Both valves possess short simple marginal pore canals in the anterior part, and barely visible ones in the posterior part. Duplicature much larger anteriorly than posteriorly in both valves. Selvage and flange not pronounced.

In the type-locality, female carapace length ranges from 0.79 to $0.86 \mathrm{~mm}$ for adult females. Mean length is $0.82 \pm 0.02 \mathrm{~mm}$. In the male specimen from Cuba the left valve measures $0.82 \times 0.38 \mathrm{~mm}$, and the right valve $0.80 \times$ $0.35 \mathrm{~mm}$. In Curaçao, female carapace lengths range from 0.69 to $0.86 \mathrm{~mm}$ in three different localities (table I). The lengths of the few specimens from other localities, e.g. in Haiti, fit within this length range. The variation in carapace length will be discussed at the end of this section.

Antennule (A 1) (fig. 4B):

I: A-1l(pl)-1m(pl), P-2l/II: A- $1 m(\mathrm{pl}) / \mathrm{III}: \mathrm{A}-$
$1 l(\mathrm{pl}) / \mathrm{IV}: \mathrm{A}-2 l, \mathrm{P}-1 \mathrm{~m} / \mathrm{V}: \mathrm{A}-2 l, \mathrm{P}-1 \mathrm{~m} / \mathrm{VI}: \mathrm{A}-2 l-$ $1 m-1 m(\mathrm{pl}) / \mathrm{VII}: \mathrm{D}-\mathrm{y}_{\mathrm{a}}-1 l(\mathrm{cs}: 1 \mathrm{ser})-2 l$.

The proportional lengths of the segments III to VII are: $1: 1.2: 1.2: 1.4: 1.3$.

Second antenna (A 2) (figs. 4C-D, 5G):

Pr: P-1 $m(\mathrm{pl}) / \mathrm{Exo}: 1 m(\mathrm{pu})-2 s / \mathrm{E} \mathrm{I}: \mathrm{P}-\mathrm{Y}-1 m(\mathrm{pu})-$ $1 s / \mathrm{E}(\mathrm{II}+\mathrm{III}): \quad \mathrm{A}-1 s(\mathrm{pu}), \quad \mathrm{P}-\mathrm{y}_{1}-1 s\left(\mathrm{t}_{1}: \mathrm{pu}\right)-$ $3 s\left(\mathrm{t}_{2}, 3,4\right), \mathrm{D}-\mathrm{y}_{2}-1 s\left(\mathrm{z}_{1}: \mathrm{cs}\right)-2 s\left(\mathrm{z}_{2}, 3\right)-2 l\left(\mathrm{G}_{1,3}: \mathrm{ser}\right)-$ $1 m\left(\mathrm{G}_{2}: \operatorname{ser}\right) / \mathrm{E}$ IV: D-2m( $\mathrm{G}_{\mathbf{M}, \mathrm{m}}$ :ser $)-1 m-1 s-\mathrm{y}_{3}$.

In contrast to Ps. geratsi the female $\mathrm{z}_{1}$ seta is transformed into a chelate seta as in Ps. serbani. In the male, E II and E III are separated and the $t$ setae are transformed into "male" $t$ setae as in Ps. geratsi, Ps. serbani, and most other Candoninae with a totally developed A2. The z setae have the typical male positions and shapes as in the species mentioned above. $G_{2}$ is smaller and more slender in the male (fig. $5 \mathrm{G}$ ).

Mandibular palp (Mdp) \& maxillula (Mxu) (figs. 4E, $\mathrm{H}$ ):

Mdp: I: In-1 $l-1 l\left(\mathrm{~S}_{1}: \mathrm{pu}\right)-1 s\left(\mathrm{~S}_{2}: \mathrm{pu}\right)-\alpha / \mathrm{II}:$ In $-4 l$ (pu)- $\beta, \mathrm{Ex}-2 m / \mathrm{III}: \mathrm{In}-2 m, \mathrm{Ex}-3 m, \mathrm{~A}-1 l-1 m / \mathrm{IV}$ : D-1 $m$ (cs:pu)-1 $m$ (cs:ser)-2s.

The chaetotaxy of the mandibular palp and the maxillula are of the same type as in Ps. geratsi.

Maxilla (Max) (figs. 4J, 5H-J):

The female maxillae have two ' $a$ ' setae instead of one as in Ps. geratsi. The shape of the male maxillar endopodites is more elongated and the two ventral spines are longer than in Ps. geratsi. The other characters are the same in both species.

Thoracopods 1 \& 2 (T 1, T 2) (figs. 4F-G):

The chaetotaxy of $\mathrm{T} 1$ and $\mathrm{T} 2$ is the same in male and female, and like that of Ps. geratsi. Only the longer seta of T 1: E III is 1.2 times the length of E IV, while in Ps. geratsi it is more than twice the length of this segment.

Furca (Fu) \& furcal attachment (Fuat) (figs. $4 \mathrm{~K}, 5 \mathrm{~F})$ :

$\mathrm{G}_{\mathrm{p}} / \mathrm{G}_{\mathrm{a}}$ is $82-92 \%, \mathrm{~s}_{\mathrm{p}} / \mathrm{G}_{\mathrm{p}}$ is $42-47 \%, \mathrm{~s}_{\mathrm{a}} / \mathrm{G}_{\mathrm{a}}$ is $10 \%, d\left(s_{p}-G_{p}\right) / R$ is $21 \% . G_{a}$ is about half of the 


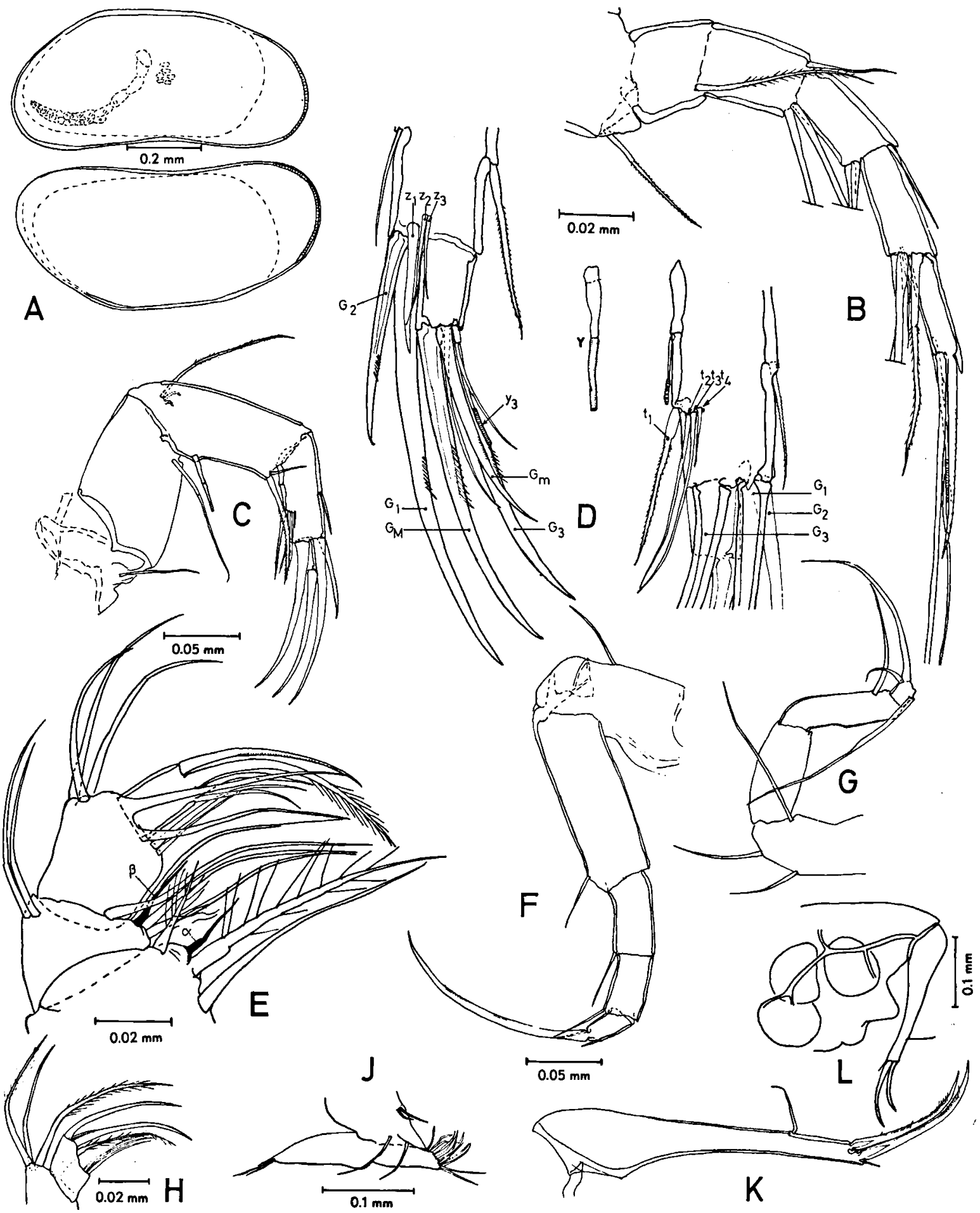

Fig. 4. Pseudocandona antilliana $\mathrm{n}$. sp. (S 79/549, Haiti, $\$$ holotype): A, right and left valve; B, antennule; C-D, second antenna, with details viewed from exterior and interior side; E, mandibular palp; F-G, first and second thoracopod; $\mathrm{H}$, maxillular palp; J, maxilla; K, furca; L, posterior part of body. 

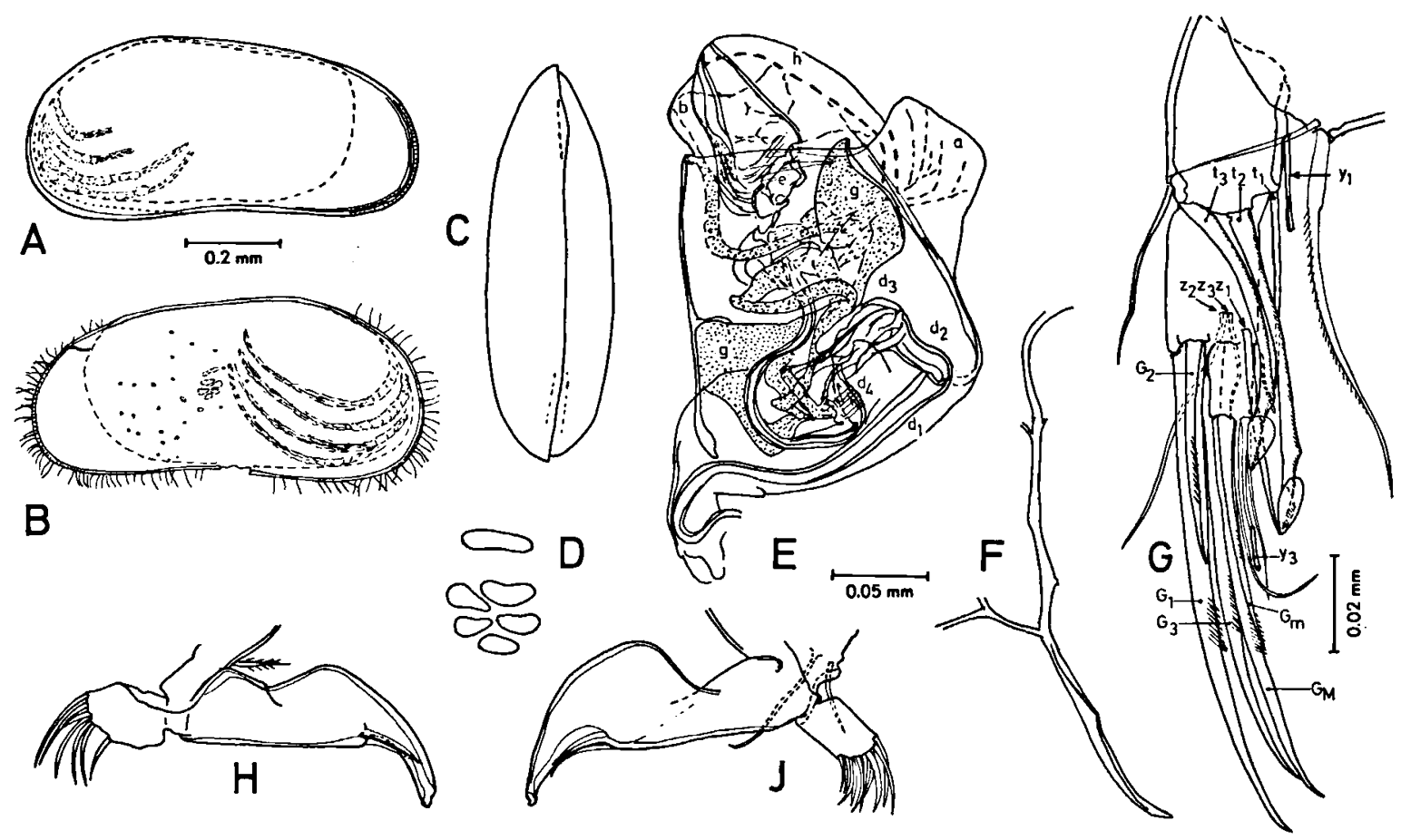

Fig. 5. Pseudocandona antilliana n. sp. (B 69/44, Cuba, $0^{\circ}$ ): A, carapace in lateral (A) and dorsal (C) view; B, left valve; D, muscle prints; E, hemipenis (for explanation see text); F, furcal attachment; G, distal part of second antenna; H-J, left and right maxillae.

length of the ramus, which is less than in $P$ s. geratsi. In Ps. geratsi the ramus is shorter and stouter. In both sexes of Ps. antilliana the furca is 13 times as long as wide, while in females of $P s$. geratsi it is $7-8$ times as long as wide (width measured at $s_{\mathrm{p}}$ ).

The furcal attachment in females of both species is the same. The attachment of the male of Ps. antilliana is probably damaged.

\section{Copulatory organs (figs. 4L, 5E):}

The female copulatory organ has a triangularly shaped obtrusion, while it is rounded in $P$ s. geratsi.

The Zenker's organ has seven whorls of spines. The hemipenis is of the typical 'Pseudocandona type, as in Ps. geratsi. Lobes ' $b$ ' and ' $h$ ' are different from those in Ps. geratsi, while lobe ' $a$ ' is practically the same, only somewhat broader. Part ' $M$ ' ( $g$ ) is totally different from that in Ps. geratsi. The distal part of this lobe is wide and terminally pointed. The lower parts of ' $\mathrm{g}$ ' are about the same as in Ps. geratsi. The sclerified parts of the bursa copulatrix (e) seem to be different from those in Ps. geratsi, but its exact homologies are difficult to ascertain. The labyrinth is the same as in Ps. geratsi.

Etymology. - The species is named after the Antilles, alluding to its very wide distribution throughout these islands.

Taxonomic remarks. - The species shows very close affinities with Ps. annae. Eventually it could be the same species. According to the drawings of Méhes (1913) the shape of male and female carapace is somewhat different. Only with the original material at hand it can be ascertained if it is the same species. However, Méhes found males as well as females in his population from Colombia near Bogotá at an altitude of $2640 \mathrm{~m}$. It is possible that the male specimen described by Furtos (1936) as Candona annae is a representative of Ps. antilliana. The similarities between her drawing of the 
hemipenis and that of the specimen from Cuba is striking, especially the shape of lobes ' $a$ ', ' $b$ ', ' $h$ ', and the lower and distal parts of ' $g$ ', which are vaguely indicated in her drawing. The shape of male maxillae and furca are the same. Only the carapace of her specimen seems to be shorter and more compact, but this could be a mistake in the drawing, because the overall shape of this carapace is the same. Ps. elliptica Furtos, 1933, from Ohio is another species which is probably closely related with Ps. antilliana. The shape of the carapace is similar but more rounded, and the male maxillae are more irregularly formed in this species.

There seem to be some differences between specimens from different islands and stations, especially in size. However, none of these differences, especially in the furca and in the shape of the carapace, is significant. One specimen from Vieques (east of Puerto Rico) is really aberrant. It is much smaller than adult specimens from other populations, but yet mature and ovigerous. Because of lack of material it was impossible to check if the population on Vieques is significantly different from the other populations.

Probably there are several subspecies in the different islands. From most stations only a few specimens are available, which makes it difficult to decide if certain differences between specimens are significant or not. This holds especially true for Venezuela, where a few specimens were found in which the distance $s_{\mathrm{p}}$ $G_{p}$ in the furca is larger than in other populations. The matter is even more complicated because the species seems to be parthenogenetic in most of the cases. As in the Candoninae in Europe, it is probably practically impossible to find differences between populations which consist only of females, while in populations with males interpopulational differences can be found. Therefore it is probably better to accept all populations as being $P$ s. antilliana until more material is available.

In Haiti at $S 79 / 518$, a source in the southwestern part of the island, a male specimen of a Pseudocandona probably related to both species described was encountered. The carapace of this specimen was destroyed. However, the shape and structures of furca, hemipenis and maxillae were clearly different from both other species. Ps. antilliana was found at about $60 \mathrm{~km}$ west and east of this station.

Carapace length. - Another character which could give some indication about differences between populations is the length of the carapace. In table I most samples containing Ps. antilliana are listed, with type of habitat and ranges of carapace length.

At Curaçao the carapace length ranges from 0.67 to $0.86 \mathrm{~mm}$. Especially in the samples from station WH 74, taken at different dates, it is clear that large differences in carapace length can be found, even in the same station. The total variation on Curaçao as a whole, is the same as in station WH 74 alone. All carapace lengths measured for samples from the other islands fall within this range too.

In Cuba, where most samples were collected in cave pools, carapace lengths vary from 0.65 to $0.89 \mathrm{~mm}$, a range even wider than at Curaçao. On Barbados two size classes were found within one sample, with a $0.06 \mathrm{~mm}$ difference in their means.

These results suggest that the variation in carapace length is not caused by genetical differences between populations, but rather by environmental factors, as found for the genera Heterocypris and Hemicypris in the Caribbean (Broodbakker, 1983a, b).

Ecology. - Ps. antilliana has a wide distribution, reaching from Venezuela, over most Antillean islands, to Haiti and Cuba, and probably even to Florida. The distribution suggests that Ps. antilliana also inhabits those Antillean islands where it has not yet been encountered. If this is true, it is strange that the species was never found on Aruba and Bonaire, islands which have been intensively sampled by both Prof. Dr. J. H. Stock and Dr. P. Wagenaar Hummelinck. It is more likely that the species sometimes reached certain islands by dispersion, and disappeared again because of un- 
TABLE I

Size range of the carapaces, and type of habitat, of most of the samples containing Pseudocandona antilliana $\mathbf{n}$. sp.

\begin{tabular}{|c|c|c|c|c|}
\hline $\begin{array}{l}\text { Island or } \\
\text { country }\end{array}$ & Station code & Type of habitat & $\begin{array}{l}\text { Size range } \\
(\mathrm{mm}) \\
(\mathrm{mean} \\
\pm \text { S.D.) }\end{array}$ & (n) \\
\hline Venezuela & S $82 / 519-523$ & interstitial of river and spring & 0.80 & (3) \\
\hline Curaçao & WH 72-72a-72b & permanent spring in walled-in basin & $0.72-0.78$ & (8) \\
\hline \multirow[t]{3}{*}{ Curaçao } & WH 74 (1936) & permanent spring in small basin & $0.67-0.73$ & (7) \\
\hline & WH 74a (1949) & permanent spring in small basin & $0.77-0.86$ & (4) \\
\hline & WH 74c (1955) & permanent spring in small basin & $0.72-0.77$ & (6) \\
\hline Curaçao & WH 77A-77b & permanent spring in cistern + overflow & $0.77-0.81$ & (9) \\
\hline \multirow[t]{3}{*}{ Barbados } & WH 788 & cemented basin in garden & $0.75-0.84$ & $(25)$ \\
\hline & & two size classes: & $0.77 \pm 0.01$ & (15) \\
\hline & & & $0.83 \pm 0.01$ & (10) \\
\hline Martinique & WH 851 & pool in rivulet & 0.77 & (1) \\
\hline La Désirade & WH 740A & pool, $30 \mathrm{~m}$ from a source & $0.69-0.70$ & (6) \\
\hline Antigua & S $78 / 43$ & large covered basin with small opening & $0.72-0.77$ & (9) \\
\hline Antigua & S 78/44 & round well, largely covered & 0.81 & (1) \\
\hline Dog Island & WH 546 & permanent, excavated small well & 0.81 & (1) \\
\hline Vieques & S $78 / 172$ & open shallow well & 0.66 & (1) \\
\hline Haiti & S $78 / 212$ & covered well & 0.81 & (2) \\
\hline \multirow[t]{2}{*}{ Haiti } & S 79/529-630- & brook, spring, & $0.73-0.79$ & (3) \\
\hline & $638-639-657$ & covered well, open well, spring & $0.84-0.86$ & (5) \\
\hline Jamaica & S $82 / 105$ & springs in riverbank & $0.69-0.75$ & (2) \\
\hline Cuba & В $69 / 1$ & cave pool & $0.65-0.73$ & (6) \\
\hline \multirow[t]{2}{*}{ Cuba } & B $69 / 18$ & cave pool & \multicolumn{2}{|c|}{ (only carapaces) } \\
\hline & & & $0.77-0.89$ & (10) \\
\hline \multirow[t]{2}{*}{ Cuba } & B $69 / 30-32 a-45 a$ & cave lake, cave pools & \multicolumn{2}{|c|}{ (only carapaces) } \\
\hline & & & $0.71-0.81$ & (17) \\
\hline \multirow[t]{3}{*}{ Cuba } & B $69 / 26$ & cave pools ("gours") & \multicolumn{2}{|c|}{ (only carapaces) } \\
\hline & & & $0.66-0.76$ & (18) \\
\hline & & & $0.71 \pm 0.03$ & (18) \\
\hline \multirow[t]{2}{*}{ Cuba } & Delamare Deboutte- & cave pools (“'gours') & $0.67-0.74$ & (13) \\
\hline & ville (1974) & & $0.70 \pm 0.025$ & (13) \\
\hline \multirow[t]{2}{*}{ Cuba } & Orghidan (1970) & no data & $0.75-0.85$ & (8) \\
\hline & & & $0.80 \pm 0.037$ & (8) \\
\hline
\end{tabular}

favourable conditions or competition with other species of ostracods.

Ps. antilliana is encountered mostly in springs, cave pools and wells, but sometimes also at the bottom of running waters. Once it was found in a water basin in a garden, where 25 specimens have been collected, which is a high number compared with the number of specimens found in other samples. In this basin it was accompanied by three other species of ostracods. In most springs and cave pools it is accompanied by Darwinulidae. In most other samples it is accompanied by Cypridopsinae, Cypretta sp., or Strandesia species.

The species is found at chlorinities ranging from 0 to $1410 \mathrm{mg} / \mathrm{l}$.

Ps. antilliana occurs mostly in more permanent habitats of low chlorinity. There is no indication in the morphological characteristics that the species is adapted to subterranean habitats. The competitive abilities of the species are assumed to be low, because it is practically 
always encountered in small numbers and in few samples, notwithstanding its wide geographical distribution.

Another explanation can be that Ps. antilliana, like Candona decora Furtos, 1933, has no resistant eggs but can survive only in a torpid state when the situation becomes unfavourable, and is therefore less easily transported from pool to pool by passive dispersion, in contrast to many Cypridinae species. This might explain the fact that the species is more or less confined to more permanent habitats, and is encountered in relatively low numbers. Low numbers and the absence of resistant eggs were recorded for $C$. decora by McLay (1978), based on observations in a temporary pool with four species of ostracods in Canada. McLay suggests that Candona's strategy of going into a torpid state when the situation becomes unfavourable is not well suited in areas with arid summers. It seems that his conclusion can be extended to explain the low number of epigean samples in which Candoninae are present, and the low number of specimens, if present.

\section{Pseudocandona caribbeana n. sp.}

(Figs. 6A-D, G, K-N, P-R, U-V)

Material. - Holotype: ZMA Ost. 150.802, one female (0.73 mm). Paratype: ZMA Ost. 150.803, one female, and some valves.

Type-locality: S 79/49, Jamaica, three holes dug in sand and gravel at the water line of the $1 \mathrm{~m}$ wide brook Brays River, bridge 25 of road A $3\left(18^{\circ} 15^{\prime} 13^{\prime \prime} \mathrm{N} 76^{\circ} 48^{\prime} 06^{\prime \prime} \mathrm{W}\right)$; 25-X-1969. Accompanying fauna: Polychaeta, Gastropoda, Insecta.

Other stations: S 79/52, Jamaica, two holes dug in gravel along the banks of the Roaring River, a $1.5 \mathrm{~m}$ wide shallow brooklet W. of Annoto $\left(18^{\circ} 14^{\prime} 42^{\prime \prime} \mathrm{N}\right.$ $\left.76^{\circ} 49^{\prime} 07^{\prime \prime} \mathrm{W}\right)$; moderate current; 26-X-1979. Accompanying fauna: Oligochaeta, Polychaeta, Cyclopidae, Gastropoda, Diptera (ZMA Ost. 150.805).

S 82/531, Venezuela, hole dug in a bank of gravel and coarse sand between large boulders in the middle of the fast running river Rio Acurigua, Acurigua, Sierra de San Luis, Edo. Falcon $\left(11^{\circ} 18^{\prime} 54^{\prime \prime} \mathrm{N} 69^{\circ} 28^{\prime} 48^{\prime \prime} \mathrm{W}\right)$; water depth $0.5 \mathrm{~m}$, width $5 \mathrm{~m}$; chlorinity $80 \mathrm{mg} / \mathrm{l}$; 5 -III-1982; 2 specimens. Accompanying fauna: Oligochaeta, Insecta; Ostracoda: Ps. geratsi n. sp. (ZMA Ost. 150.804).

Description

Only females of this species are known.
Carapace (figs. 6A-D):

The carapace is reticulate by irregularly shaped pits. The colour is whitish transparent. In dorsal view greatest width at $50 \%$ of the length, being $35 \%$ of the length. Because of the straight dorsal margin, the greatest height can be found at one-third as well as at two-thirds of the length. The dorsal margin passes with an angle of $30^{\circ}$ into the anterior, and of $40^{\circ}$ into the posterior margin. Anterior and posterior margins are rounded. Ventral margin slightly sinuate. Duplicature anteriorly twice as wide as posteriorly. Marginal pore canals simple and straight, less inconspicuous in the left valve. Selvage and flange not pronounced. Valves moderately hairy. Muscle scars as typical of the Candoninae.

The female holotype has a carapace length of $0.73 \mathrm{~mm}$. The paratype measures $0.71 \times 0.36$ $\mathrm{mm}$. The carapace length in station $\mathrm{S} 79 / 52$ ranges from 0.70 to $0.75 \mathrm{~mm}$. The female from $\mathrm{S} 82 / 537$, Venezuela, has a carapace length of $0.62 \mathrm{~mm}$.

Antennule (A 1) (fig. 6G):

Chaetotaxy the same as in the other Pseudocandona species. The proportional lengths of the segments III to VII are: $1: 1.4: 1.4: 1.7: 1.5$, which is nearly the same as in Ps. geratsi. The aesthetasc $y_{a}$ is 2.2 times as long as segment VII, and the shortest seta of this segment is 2.6 times as long, which is relatively longer than in both other species.

Second antenna (A 2) (fig. 6K):

The chaetotaxy seems to be the same as in Ps. geratsi, but no claw-like $\mathrm{z}_{1}$ is visible. Only two $\mathrm{t}$ setae are visible, but probably there are more. The aesthetasc $y_{3}$ is $48 \%$ of the length of $G_{M}$, which is about the same length as in Ps. geratsi $(43 \%)$. The $z$ setae are 1.5-2.5 times as long as segment E IV.

The chaetotaxy of the mandibular palp, maxillula, maxilla, and thoracopods 1 \& 2 (figs. 6L-N, P-R), is identical with that in Ps. geratsi.

Furca (Fu) \& furcal attachment (Fuat) (fig. $6 \mathrm{U})$ : 
The general shape of the furca is the same as in females of Ps. geratsi. $\mathrm{G}_{\mathrm{a}} / \mathrm{R}$ is the same $(65 \%)$, $\mathrm{G}_{\mathrm{p}} / \mathrm{G}_{\mathrm{a}}$ is $89 \%, \mathrm{~s}_{\mathrm{a}} / \mathrm{G}_{\mathrm{a}}$ is $19 \%, \mathrm{~s}_{\mathrm{p}} / \mathrm{G}_{\mathrm{p}}$ is $55 \%$, values slightly larger than or the same as in $P$ s. geratsi. The distance $\mathrm{s}_{\mathrm{p}}-\mathrm{G}_{\mathrm{p}}$ is $22 \%$ of $\mathrm{R}$, which is about the same as in females of Ps. geratsi $(19 \%)$. The furcal attachment is the same as in Ps. geratsi females.

Copulatory organs (fig. 6V):

The shape of the posterior part of the female copulatory organ is rounded and the same as in Ps. geratsi.

Taxonomic remarks. - See after the description of the next species.

Ecology. - Only a few samples with this species were found. In Jamaica it was found in sand and gravel beds of small brooklets (1-1.5 m wide), of unknown chlorinity (but fresh). In Venezuela the species was found in coarse sand with pebbles on the bank of a small river, also fresh (chlorinity $80 \mathrm{mg} / \mathrm{l}$ ), together with $P$ s. geratsi. According to the definition of Danielopol (1980b) this species is assumed to be "true interstitial" until further evidence proves the contrary.

\section{Pseudocandona cubensis $n$. sp. \\ (Figs. 6E-F, H-J, O, S-T, W)}

Material. - Holotype: 1 female. Paratypes: 1 female and 4 juveniles, 1 valve (ZMA Ost. 150.809).

Type-locality: B 73/67, Cuba, a few enormous pools in the Cueva de las Represas, which is part of Cueva del Segundo Cauce of the Gran Caverna de Santo Tomas, Prov. Pinar del Rio $\left(22^{\circ} 23^{\prime} \mathrm{N} 83^{\circ} 57^{\prime} \mathrm{W}\right)$; depth down to $3 \mathrm{~m}$; a temporary river had filled up the pools; 12-IV-1973. Accompanied by an unknown ostracod species.

Other station: B 73/37, Cuba, cave rimstone pools ("gours"), in Cueva la Campana, in the mountain Loma de Cupeycillo, $20 \mathrm{~km} \mathrm{~W}$. of Gibara, Prov. Granma $\left(21^{\circ} 12^{\prime} \mathrm{N} 76^{\circ} 29^{\prime} \mathrm{W}\right)$; fine sediment; 8-III-1973; 8 specimens (1 adult) (ZMA Ost. 150.843). Both samples collected by L. Botosaneanu.

Geographical distribution known. - Cuba.

\section{Description}

Only females of this species are known.
The chaetotaxy of all appendages is practically the same as in Ps. caribbeana. Only differences will be indicated.

\section{Carapace (figs. 6E-F):}

The carapace shape, reticulation, and other characters, are the same as in Ps. caribbeana. The two females from the type-locality are sized: $0.69 \times 0.33 \mathrm{~mm}$ and $0.71 \times 0.35 \mathrm{~mm}$. The female from $B \quad 73 / 37$ has a length of 0.58 $\mathrm{mm}$.

Antennule (A 1) (fig. 6H):

The proportional lengths of the segments III to VII are: $1: 1.4: 1.3: 1.4: 1.4$, which means that only segment VI is relatively shorter than in Ps. caribbeana. However, aesthetasc $y_{a}$ and the shortest seta of segment VII are much longer, 3.9 and 3.2 times as long as segment VII, respectively.

Second antenna (A 2) (fig. 6J):

The $z$ setae and $G_{2}$ are relatively shorter, and aesthetascs $\mathrm{Y}$ and $\mathrm{y}_{3}$ are longer, $\mathrm{y}_{3}$ is $65 \%$ of the length of $G_{M}$.

The chaetotaxy of the mandibular palp, maxillula and maxilla is the same as in Ps. caribbeana.

Thoracopod 1 (T 1) (fig. 6O):

Segment $\mathrm{E} I$ is relatively longer than in Ps. caribbeana, and the longer seta on segment E III is much longer, being 3.8 times the length of $\mathrm{E}$ IV. The proportional lengths of segments and claw are: 5.1: 2.6: 2.0 (2.2 in Ps. caribbeana) : 1 : 6.6 .

Thoracopod 2 (T 2) (fig. 6S):

On the protopodite of $\mathrm{T} 2$ there is only one seta instead of two at the exterior side.

Furca (Fu) (fig. 6T):

The furca is somewhat more elongate than in Ps. caribbeana. However, the differences are only minor. The anterior claw is somewhat longer, and the posterior seta is shorter. 


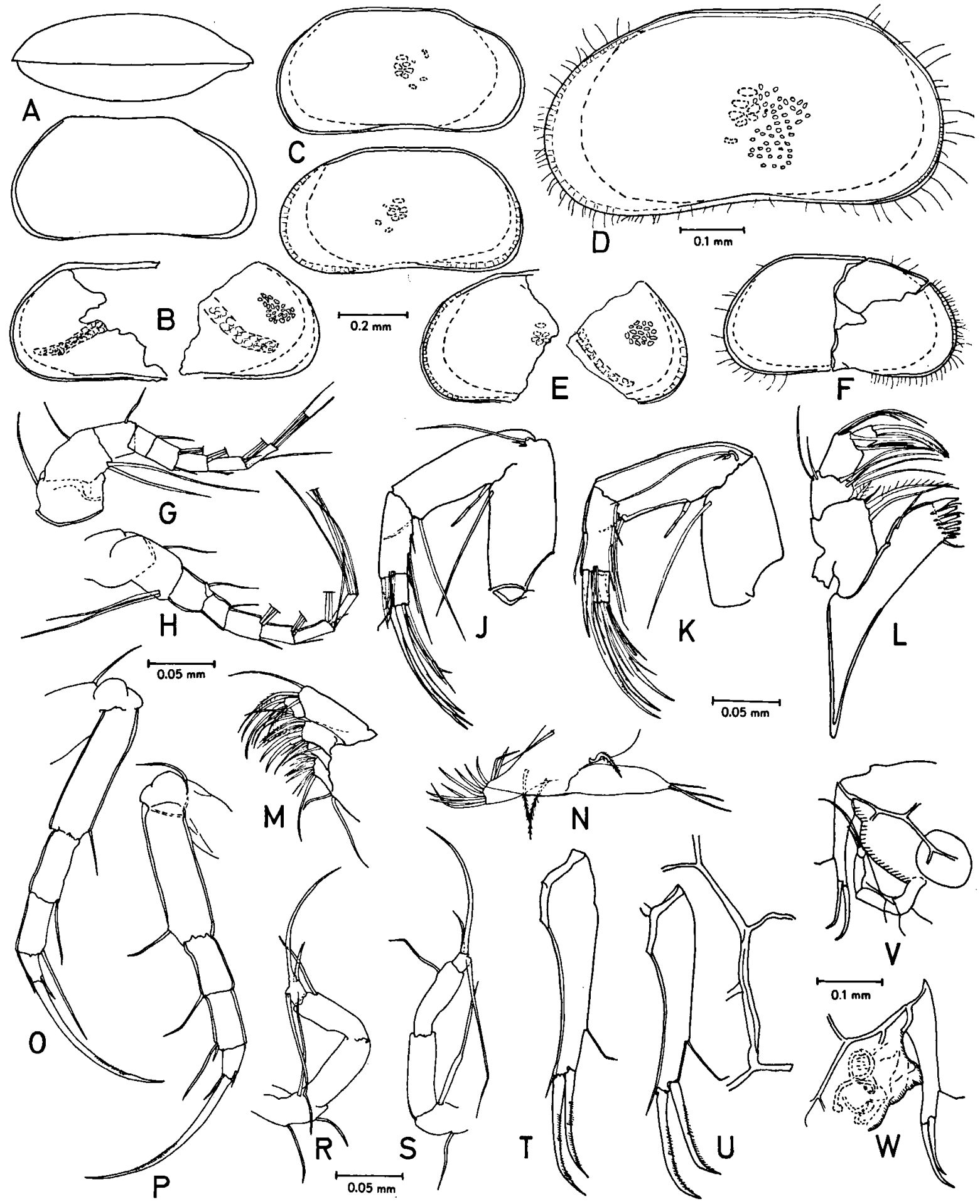

Fig. 6. A-D, G, K-N, P-R, U-V, Pseudocandona caribbeana n. sp. (A-C, G-V, S 79/49, Jamaica: A-B, V, 9 no. 2; G, K-N, P-R, U, \& holotype; D, S 82/537, Venezuela, \& no. 1); E-F, H-J, O, S-T, W, Pseudocandona cubensis n. sp. (B 73/67, Cuba; E, O, S-T, $\$$ holotype; F, H-J, W, $\$$ no. 2): A, carapace in dorsal and lateral view; B, parts of right and left valve; $C$, empty valves; $D-E$, left valves; F, right valve; $G-H$, antennules; J-K, second antennae; $L$, mandible with mandibular palp; M, maxillula; N, maxilla; O-P, first thoracopod; R-S, second thoracopod; T-U, furcas with furcal attachment; V-W, posterior parts of body. 
Copulatory organs (fig. 6W):

The shape of the female copulatory organ is like that of Ps. antilliana, with a triangular obtrusion posteriorly.

Taxonomic remarks about $P$ s. caribbeana and Ps. cubensis. - Both species are closely related. Only one mature female of Ps. caribbeana was found in Venezuela, which was notably smaller than the specimens from Jamaica. The differences between this specimen and the others from Jamaica were not large enough to define a new species. More material is needed to discover eventual differences between the populations from Jamaica and Venezuela.

The carapace shape of specimens from Cuba, Jamaica and Venezuela is practically the same. The differences between the Cuban and Jamaican populations are small but consistent, especially in the shape of the female copulatory organs.

Concerning the structure of the mandibular palp, both species belong to the rostrata group, because there are $2+3$ setae present at the interior side of the second segment. The shape of the carapace is the same as that in two caverniculous species from Indiana (U.S.A.), Ps. marengoensis and Ps. jeanneli, both described by Klie (1931). Klie (1938) provided a table with relative lengths and numbers of some setae of thoracopod 2 and furca. Most of these characters seem to be very variable within the rostrata group, and have limited value for deciding about the subgeneric status of the species in question. Most European subterranean species belong to the $P$ s. rostrata group, many having more or less rounded, somewhat trapezoidal carapaces. However, the carapaces of the two Caribbean species have most affinities with those of the species from Indiana, having straight dorsal margins and reticulated valves. It is proposed to place these four species in a new group, the caribbeana group, which, like the rostrata group, has $2+3$ setae at the interior side of segment II of the mandibular palp, and furthermore the following characters:

(1) Carapace trapezoidal, with rounded anterior and posterior margins, and a straight dorsal margin of variable length. Surface reticulated by way of small round and irregularly shaped pits. Carapace length 0.62 to 0.75 $\mathrm{mm}$.

(2) T 2: the short distal seta of E IV is 2 to 2.5 times the length of E IV. E II and E III are fused. Protopodite with 2 or 3 setae.

(3) Furca: stout with strong claws, which are straight at first and bent at the tips, armed with two rows of small spines. Claw $G_{a}$ is about 0.6 times the length of the ramus. Seta $s_{p}$ is as long as or longer than the distance $s_{p}-G_{p}$.

It seems that the species of the caribbeana group are parthenogenetic.

Ecology of Ps. cubensis. - Two samples containing the species were from cave pools in Cuba. Therefore the species is supposed to be hypogean according to the definition of Danielopol (1980b), until other evidence proves the contrary.

\section{A NEW HYPOGEAN GENUS FROM HAITI AND CUBA}

In some wells of Haiti a new genus of Candoninae was discovered. Candonopsis cubensis Danielopol, 1978, from Cuba, appeared to have strong affinities with this genus and was therefore placed in another subgenus of the new genus.

\section{Caribecandona $\mathrm{n}$. gen.}

The new genus is close to the genus Candonopsis. In both genera the maxillar exopodite consists of three setae, the furca has no posterior seta, and thoracopod 2 possesses a seta at the second endopodal segment. The genus Caribecandona has the first two characters also in common with the genus Cryptocandona Kaufmann, 1900, and part of the genus Mixtacandona Klie, 1938.

The carapace shape of Caribecandona is trapezoidal or triangular (with trapezoidal valves), while in most Candonopsis it is elongated. Except for the sexual dimorphism of the second antenna, which is common in the Candoninae, the male also has a lateral pro- 
TABLE II

Differential characteristics of the two subgenera of Caribecandona n. gen.

\begin{tabular}{|c|c|c|}
\hline $\begin{array}{l}\text { Characteristics } \\
\text { of }\end{array}$ & $\begin{array}{l}\text { Caribecandona n. subgen. } \\
\text { type-species: } C \text {. trapezoidea }\end{array}$ & $\begin{array}{l}\text { Cubacandona } \mathrm{n} \text {. subgen. } \\
\text { type-species: } C \text {. cubensis }\end{array}$ \\
\hline A 1 & 6 segments, III and IV fused & 7 segments \\
\hline A 2 in male & $\begin{array}{l}4 \text { endopodal segments, } \\
2 \text { transformed t setae }\end{array}$ & $\begin{array}{l}\text { E(II + III) fused, } \\
\text { t setae not transformed }\end{array}$ \\
\hline $\begin{array}{l}\text { Distal claws } \\
\text { of } \mathrm{A} 2 \text { and } \mathrm{T} 1\end{array}$ & 1 short row of denticles & $\begin{array}{l}1 \text { short row and distal } \\
\text { blade-like structure }\end{array}$ \\
\hline T 2: Pr: Ex & 2 setae & 1 seta \\
\hline $\begin{array}{l}\text { Distal claws } \\
\text { of furca }\end{array}$ & $\begin{array}{l}1 \text { claw and } 1 \text { spine } \\
\left(G_{p} \text { reduced to spine }\right)\end{array}$ & 2 claws \\
\hline Hemipenis: $\begin{array}{r}a_{1} \\
a_{2}\end{array}$ & $\begin{array}{l}\text { rounded } \\
\text { acuminate }\end{array}$ & $\begin{array}{l}\text { quadrate } \\
\text { rounded }\end{array}$ \\
\hline
\end{tabular}

tuberance at the interior side of the fourth endopodal segment, in contrast to the other Candoninae. The third segment of the mandibular palp is 2.7 times the length of the fourth segment, while it is 1-1.5 times that length in Candonopsis. The shape of the male maxillar endopodites is also different compared with Candonopsis. In Candonopsis the proximal part is swollen and progresses smoothly in the elongated narrow distal part, which does not possess a terminal soft claw, left and right maxillae are asymmetrical. In Caribecandona they are more symmetrical, more elongate and narrow, and longitudinally twisted. They have a strongly developed subterminal claw accompanied by a small spine, and terminate in soft claws.

The lateral shield of the hemipenis consists of a proximal and a distal lobe, $a_{1}$ and $a_{2}$, while in Candonopsis there is only one lateral lobe a. The furcal claw(s) possess no hooks and are long compared with the ramus $(0.75-1.0$ times as long).

The genus Caribecandona can be divided into two subgenera:

(1) Caribecandona n. subgen., with the typespecies Caribecandona trapezoidea, which is one of the three new species described in this article. The subgenus is probably endemic to Haiti.

(2) Cubacandona n. subgen., with the typespecies Candonopsis cubensis, which is the single presently known species of this subgenus, and probably endemic to Cuba. A differential diagnosis of the two subgenera is given in table II.

\section{DESCRIPTION OF THREE NEW SPECIES OF CARIBECANDONA S. STR., FROM HAITI}

Caribecandona trapezoidea $n$. sp.

(Figs. 7A-B, 8 A-G, 9A-E, 10A-G, 11E-F)

Material. - Holotype: 1 female (ZMA Ost. 150.794). Allotype: 1 male; paratypes: 1 male and 2 females dissected, and about 35 undissected males and females.

Type-locality: S 78/203, Haiti, round covered well near a house in Gressier, N. side of road D 200, Dépt. de l'Ouest $\left(18^{\circ} 32^{\prime} 23^{\prime \prime} \mathrm{N} 72^{\circ} 31^{\prime} 13^{\prime \prime} \mathrm{W}\right)$; diam. $1 \mathrm{~m}$; water table at 2.5 $\mathrm{m}$, water depth $0.3 \mathrm{~m}$; chlorinity $40 \mathrm{mg} / \mathrm{l}$; Cvetkov net; 5-V-1978. Accompanying fauna: Oligochaeta, Cyclopidae, Thermosbaenacea, mosquito larvae; Ostracoda: Cypretta sp.

Other stations: S 79/533, Haiti, Groureau well, at Groureau, hamlet of Cazeau, Croix des Missions, Dépt. de l'Ouest (near the road on a private property) $\left(18^{\circ} 34^{\prime} 53^{\prime \prime} \mathrm{N} 72^{\circ} 16^{\prime} 16^{\prime \prime} \mathrm{W}\right)$; rich in sediment; water table at $3 \mathrm{~m}$, water depth $1.75 \mathrm{~m}$; 10-XI-1979; 38 specimens. Accompanying fauna: Cyclopidae, Harpacticoidea, Thermosbaenacea, hadziid amphipods, Insecta; Ostracoda: Chlamydotheca unispinosa (Baird, 1862).

In the following six stations in Haiti, only one or two specimens were found, all were collected with a Cvetkov net:

S 78/205-206, two open wells close to the road from Gressier to Léogâne, near rhum distillery, Dépt de l'Ouest $\left(18^{\circ} 32^{\prime} 27^{\prime \prime} \mathrm{N} 72^{\circ} 33^{\prime} 50^{\prime \prime} \mathrm{W}\right)$; diam. $0.7 \mathrm{~m}$; water table at 5 
$\mathrm{m}$, depth 1-1.5 m; dug in stone and black soil; chlorinity $40 \mathrm{mg} / \mathrm{l} ; 5-\mathrm{V}-1978$. Accompanying fauna: Cyclopidae, mosquito larvae; Ostracoda: Strandesia longula, S. stocki, Chlamydotheca unispinosa.

S 79/536, open well of Thérèse Célamy, Groureau, Cazeau, Croix des Missions, Dépt. de l'Ouest $\left(18^{\circ} 35^{\prime} 03^{\prime \prime} \mathrm{N} 72^{\circ} 16^{\prime} 23^{\prime \prime} \mathrm{W}\right)$; dug in accretion of land; water table at $3 \mathrm{~m}$, water depth $2.8 \mathrm{~m}$; chlorinity $18 \mathrm{mg} / \mathrm{l}$; 10-XI-1979. Accompanying fauna: Cyclopidae, Thermosbaenacea, hadziid Amphipoda, Diptera; Ostracoda: Strandesia stocki, Chlamydotheca unispinosa, Stenocypris major.

S 79/560, open well of Jacques Simein, at Marigot, E. of the village, Dépt. du Sud-Est $\left(18^{\circ} 13^{\prime} 51^{\prime \prime} \mathrm{N} 72^{\circ} 18^{\prime} 52^{\prime \prime} \mathrm{W}\right)$; masonry until the bottom; clean, water table at $4 \mathrm{~m}$, water depth $1 \mathrm{~m}$; chlorinity $31 \mathrm{mg} / \mathrm{l} ; 16-\mathrm{XI}-1979$. Accompanying fauna: Cyclopidae, Anopsilana acanthura (Notenboom, 1981) (cirolanid Isopoda), hadziid Amphipoda, Typhlatya (Decapoda); Ostracoda: Strandesia longula, S. stocki, Chlamydotheca unispinosa, Cypretta sp.

S 79/591, well Frank Mezidor, at the end of St. Marc on the new road to Port au Prince, Dépt. de l'Artibonite $\left(19^{\circ} 05^{\prime} 29^{\prime \prime} \mathrm{N} 72^{\circ} 42^{\prime} 04^{\prime \prime} \mathrm{W}\right)$; covered; muddy; dug in sand; water table at $7.3 \mathrm{~m}$, water depth $1.7 \mathrm{~m}$; chlorinity $45 \mathrm{mg} / \mathrm{l}$; 22-XI-1979. Accompanying fauna: Oligochaeta, Cyclopidae, Diptera; Ostracoda: Strandesia stocki.

S 79/597, well "Portail Guêpe", at Saint Marc, on the road to Gonaïves, about $100 \mathrm{~m}$ from the sea, Dépt. de l'Artibonite $\left(19^{\circ} 07^{\prime} 23^{\prime \prime} \mathrm{N} 72^{\circ} 41^{\prime} 44^{\prime \prime} \mathrm{W}\right)$; dug in limestone; water table at $2.5 \mathrm{~m}$, water depth $0.5 \mathrm{~m}$; chlorinity $230 \mathrm{mg} / \mathrm{l} ; 22-\mathrm{XI}-1979$. Accompanying fauna: Cyclopidae, Cladocera, Insecta; Ostracoda: Strandesia stocki: Cypretta sp.

S 79/606, well of Irène Nelson, at Verrettes on the large road along the Rivière de l'Artibonite, Dépt. de l'Artibonite $\left(19^{\circ} 05^{\prime} 46^{\prime \prime} \mathrm{N} 72^{\circ} 29^{\prime} 45^{\prime \prime} \mathrm{W}\right)$; dug in sand; partly walled-in; water clear; partly covered; water table at 1.8 $\mathrm{m}$, water depth $2 \mathrm{~m}$; chlorinity $190 \mathrm{mg} / \mathrm{l} ; 23-\mathrm{XI}-1979$. Accompanying fauna: Cyclopidae, fragment of hadziid amphipod; Ostracoda: Stenocypris major.

\section{Description}

Carapace (figs. 7A-B, 8A-F):

The carapace is whitish transparent. The surface is covered by large elongate polygonal markings, composed of small granulations, moderately hairy, with longer hairs posteriorly than anteriorly. Muscle scars as typical of the Candoninae.

In dorsal view greatest width at $50 \%$ of the length, being $40 \%$ of the length. Greatest height can be from about one-third to twothirds of the length, because of variation in the shape and breadth of the dorsal ridge. Left valve larger than and overlapping the right valve at all sides. Height $55-60 \%$ of length. Dorsal margin straight and narrow in the right valve. In the left valve the dorsal ridge is wider, with a more or less straight inner margin and a rounded outer margin.

The dorsal margin passes with an angle of $30^{\circ}$ and a slight indentation in the right valve, in the broadly rounded anterior margin. The dorsal margin passes with an angle of $45^{\circ}$ in the posterior margin, which is at first straight, but at the end rounded, when passing into the ventral margin. Ventral margin more or less straight.

Duplicature twice as wide anteriorly as posteriorly. Marginal pore canals distinct anteriorly as well as posteriorly, anteriorly wider and more pronounced, straight and simple. There are only minor differences between males and females.

Carapace length ranges from 0.64-0.70 mm for males and females in the type-locality, with a mean carapace length for adult specimens of: $0.67 \pm 0.02 \mathrm{~mm}(n$ females $=11, n$ males $=$ 10). In sample $S 79 / 533$ there was a larger range in carapace length, with three size classes: 0.48 to $0.51 \mathrm{~mm}(n=6) ; 0.58$ to 0.67 $\mathrm{mm}(n=12)$; and 0.71 to $0.73 \mathrm{~mm}(n=5)$, of which the cause is unknown.

The few animals found in other samples varied from 0.67 to $0.77 \mathrm{~mm}$ in length. Some variation in carapace shape is shown in figs. $8 \mathrm{~A}-\mathrm{G}$. This variation is also found within samples.

Antennule (A 1) (fig. 9B):

I: A-2 $m$, P-2l/II: A-1 $m /(\mathrm{III}+\mathrm{IV})$ : A-2l, P-1s/V: $\mathrm{A}-2 l, \quad \mathrm{P}-1 s / \mathrm{VI}: \mathrm{A}-2 l, \mathrm{P}-1 l-1 m / \mathrm{VII}: \mathrm{D}-1 l\left(\mathrm{y}_{\mathrm{a}}\right)-$ $1 m-2 l$.

Segments III and IV are fused and the former segment III does not carry an anterior seta anymore. The proportional lengths of the segments (III + IV) to VII are: 2.7: 1.2: 1.3: 1 . The aesthetasc $y_{a}$ is very long, being twice the length of segment (III + IV).

Second antenna (A 2) (figs. 9A, C):

Pr: P-1 $m /$ Exo: $2 s-1 m /$ E I: P-Y-1l-1s/.....

ㅇ : E (II + III): A-1s, P- $\mathrm{y}_{1}-3 m\left(\mathrm{t}_{1}, 2,3\right)-1 s\left(\mathbf{t}_{4}\right)$, 

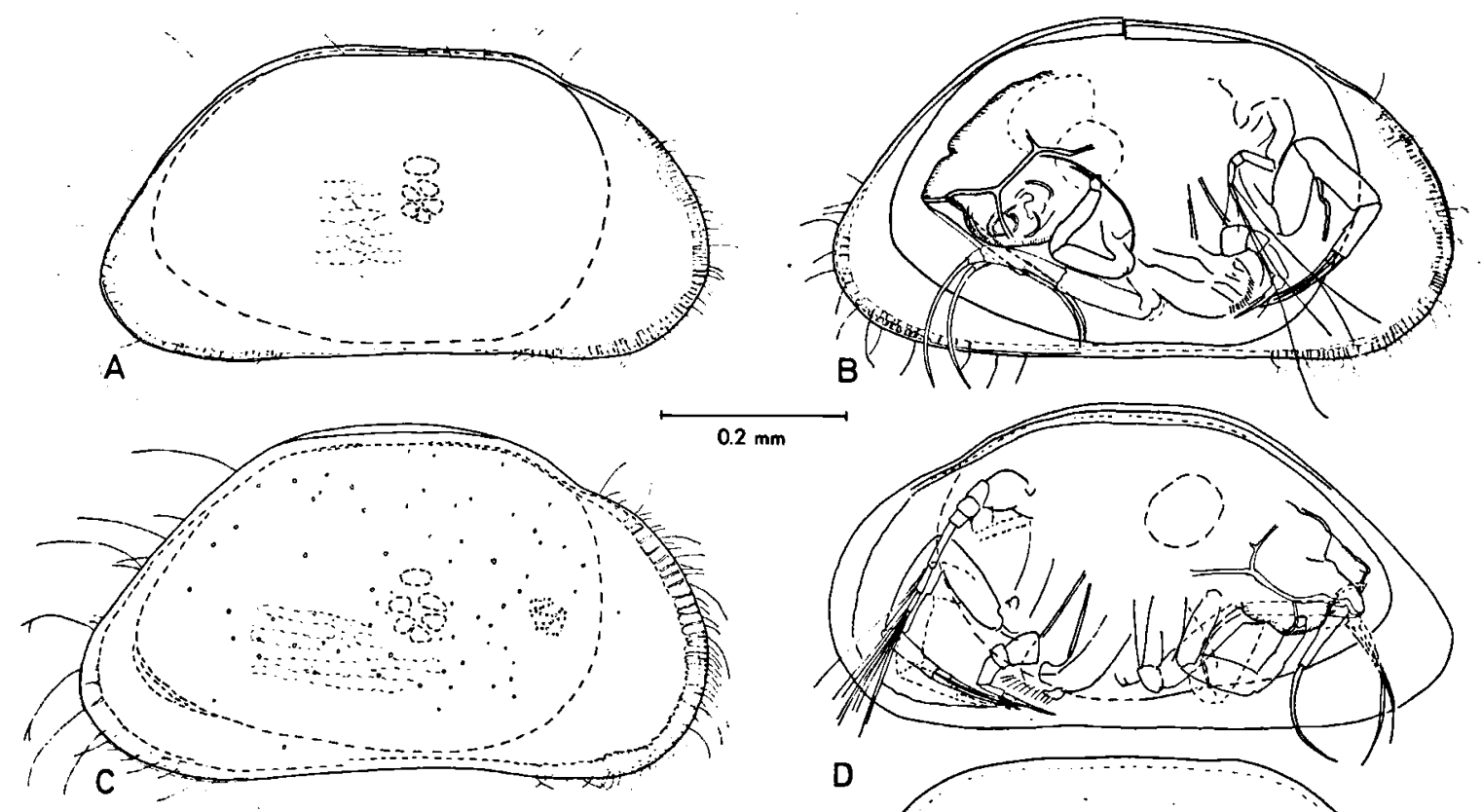

$0.2 \mathrm{~mm}$
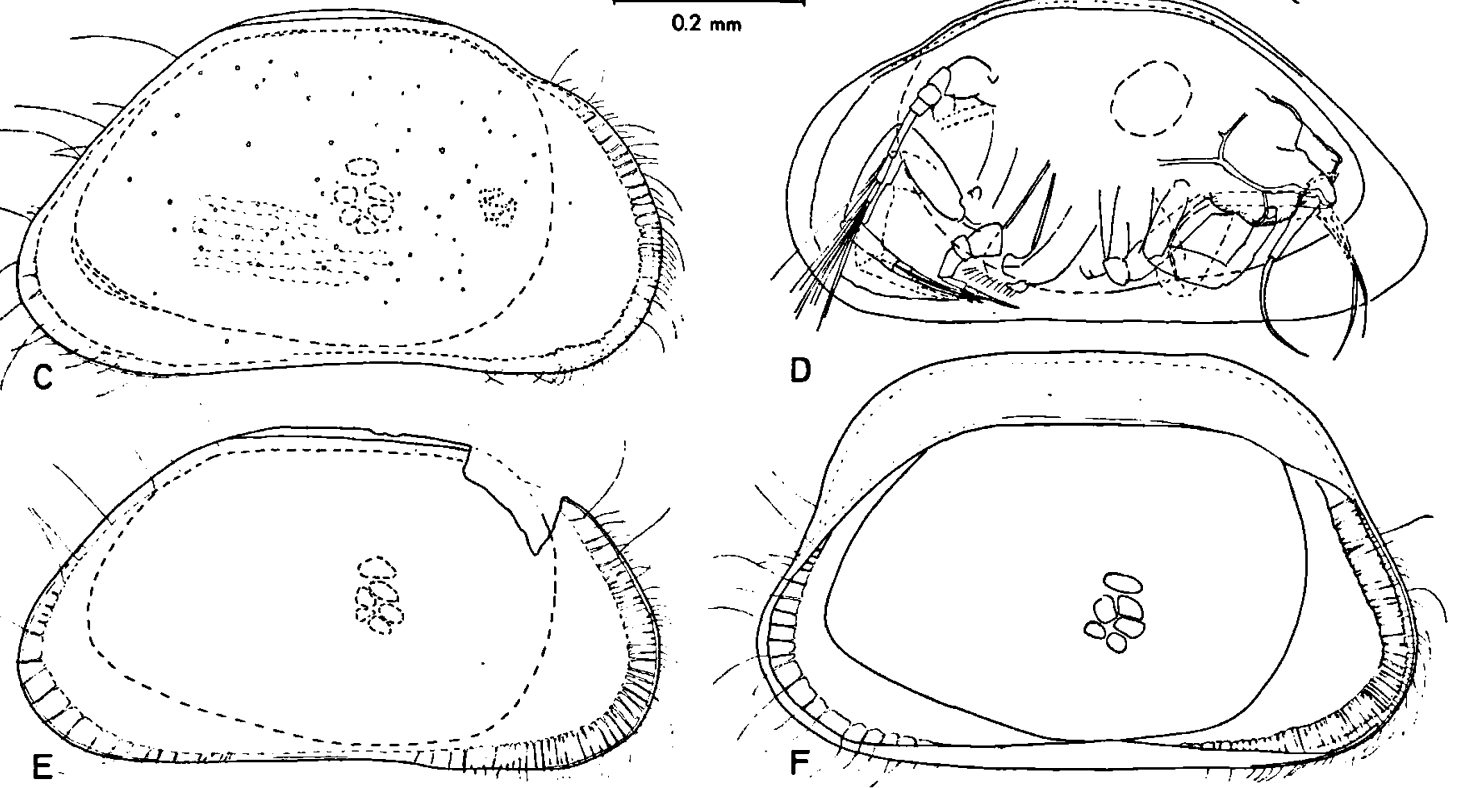

Fig. 7. A-B, Caribecandona trapezoidea n. gen., n. sp. (S 78/203, Haiti, $Q$ holotype); C-D, Caribecandona auricularia n. sp. (S 79/578, Haiti, 9 holotype); E-F, Caribecandona ansa n. sp. (S 79/601, Haiti, $\$$ holotype): A, C-E, right valves; B, F, left valves; $B$, left valve with undissected animal; $D$, right valve with undissected animal.

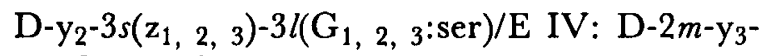
$1 m\left(\mathrm{G}_{\mathrm{m}}\right)-1\left(\mathrm{G}_{\mathrm{M}}: \mathrm{ser}\right)$.

O": E II: A-1s, P-y $-1 m\left(\mathrm{t}_{1}\right), \mathrm{Ex}-2 l\left(\mathrm{t}_{2}, 3\right)-1 s\left(\mathrm{t}_{4}\right) / \mathrm{E}$ III: $\quad \mathrm{D}(\mathrm{Ex})-\mathrm{y}_{2}-1 s\left(\mathrm{z}_{1}: \mathrm{cs}\right)-1 s\left(\mathrm{G}_{2}: \mathrm{cs}\right)-1 l\left(\mathrm{G}_{3}: \mathrm{ser}\right)$, $\mathrm{D}(\mathrm{In})-2 s\left(\mathrm{z}_{2}, 3\right)-1 l\left(\mathrm{G}_{1}: \mathrm{ser}\right) / \mathrm{E}$ IV: D-1l( $\left.\mathrm{G}_{\mathrm{M}}: \mathrm{ser}\right)-$ $1 s\left(\mathrm{G}_{\mathrm{m}}: \mathrm{cs}\right)-2 m-\mathrm{y}_{3}$.

In the female, claw $G_{2}$ is normally developed, while in the male it is reduced to a claw-like seta. The chaetotaxy of the male is as typical of most Candoninae with male $t$ setae and transformed $z$ setae; seta $z_{3}$ is tiny, and $G_{m}$ is also much reduced. Segment IV has a protuberance at the anterior side which is typical of the genus. The structure of the distal part of the second antenna (especially $z$ and $G$ setae) is the same as in C. cubensis. However, the armature of the distal claws is different.

Aesthetasc $\mathrm{Y}$ is strongly developed, as in $C$. cubensis and Candonopsis putealis Klie, 1932. This strongly indicates a subterranean mode of life. Aesthetasc $y_{3}$ is $60 \%$ of the length of $G_{M}$.

Mandibular palp (Mdp) (fig. 9D):

I: $\operatorname{In}-1 m(\mathrm{pu})-1 m\left(\mathrm{~S}_{1}: \mathrm{pu}\right)-1 s\left(\mathrm{~S}_{2}: \mathrm{pa}\right)-\alpha / \mathrm{II}: \mathrm{Ex}-2 s$, In-1m(pu)-1s( $\beta$ :pu)-3l(pu)/III: Ex-1l-1m-1s, In$1 m-2 s, \mathrm{~A}-1 m-1 s / \mathrm{IV}$ [fused with $1 m$ (cs:ser)]: Ex$1 m$, In- $1 m-1 s$.

The structure of the mandibular palp is the same as in C. cubensis. The fourth segment is 

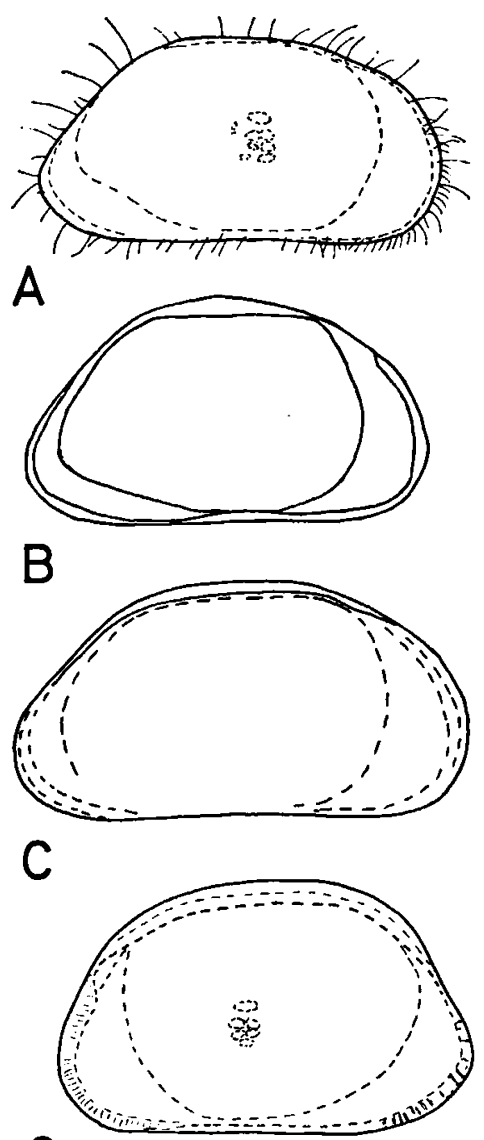

G
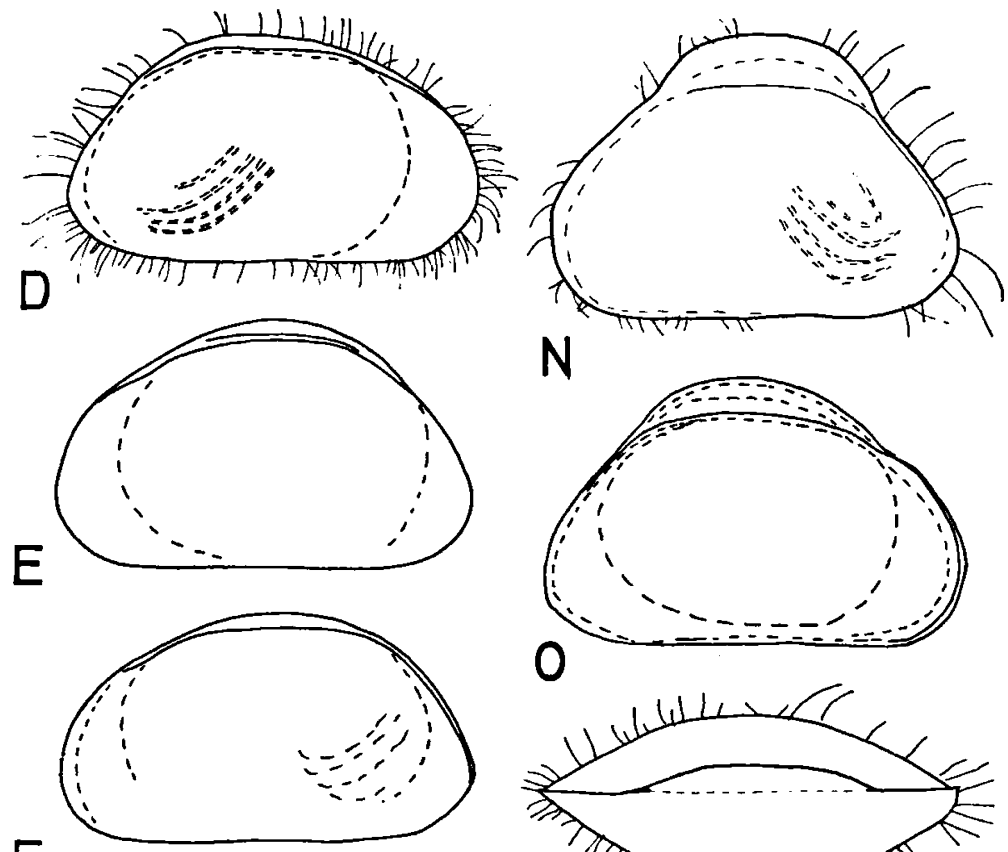

F
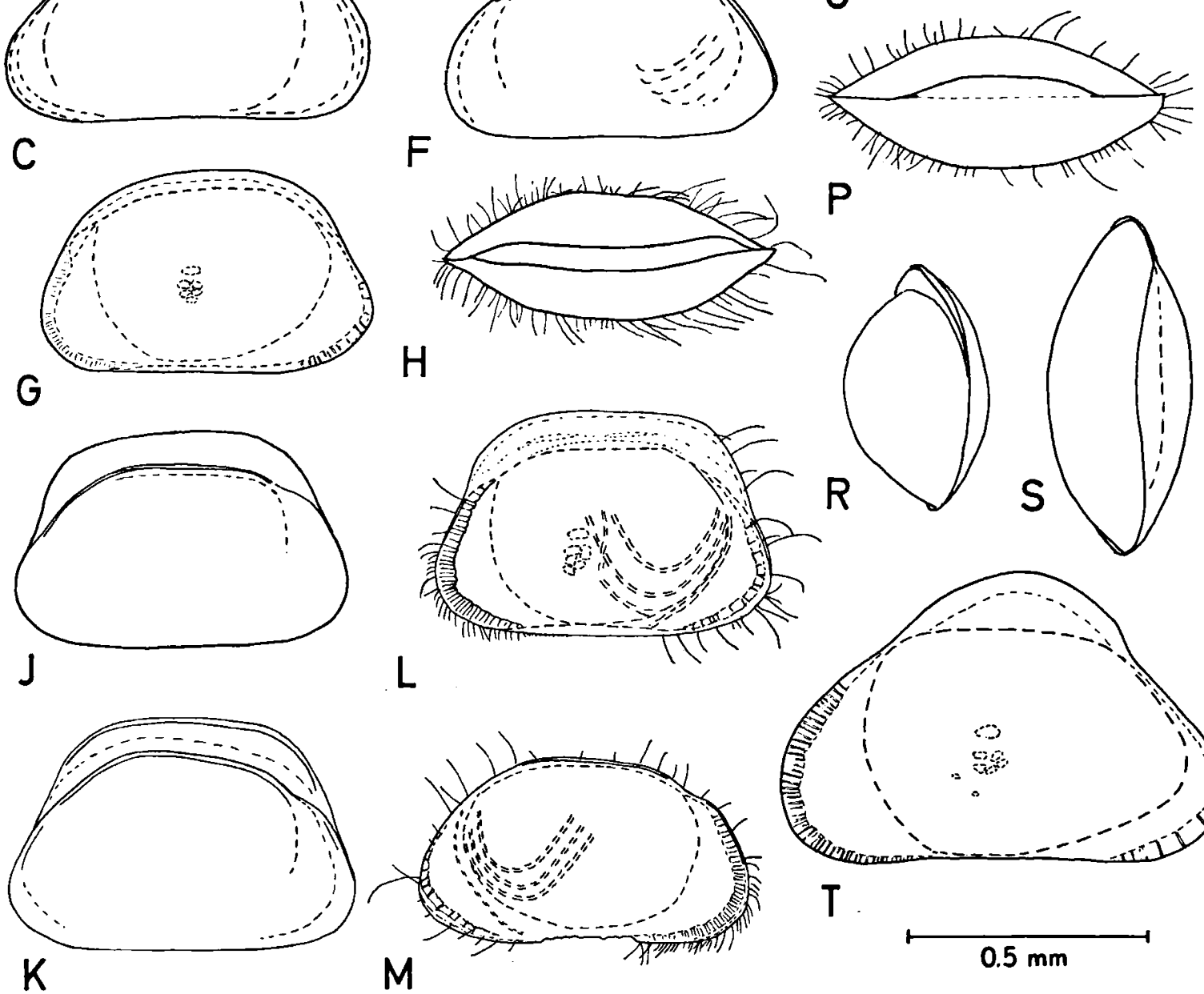

$\mathrm{H}$
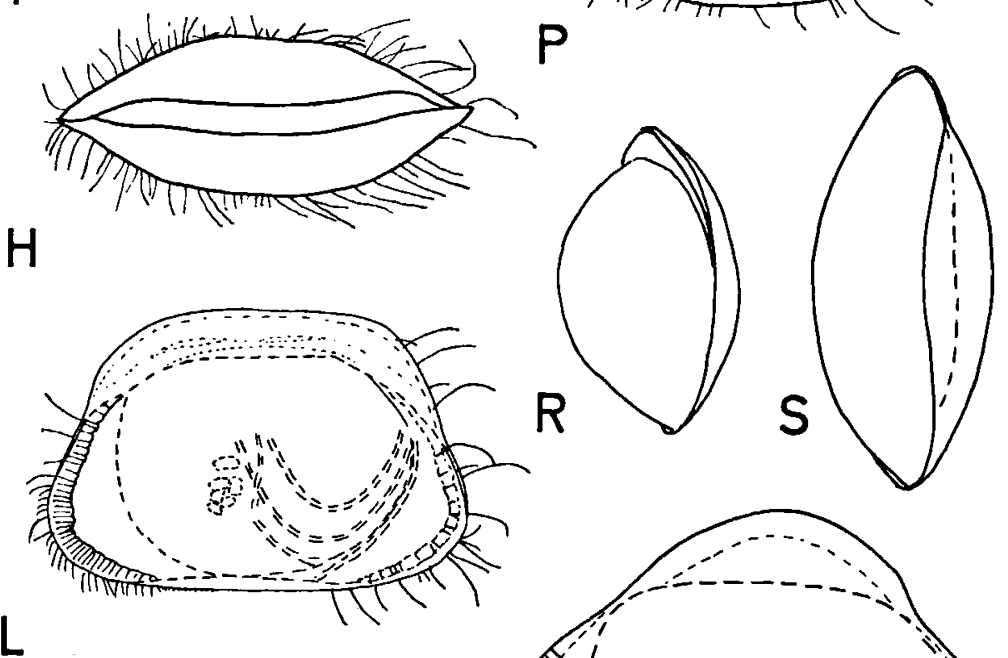

Fig. 8. A-F, Caribecandona trapezoidea n. gen., n. sp. (A-B, D-G, S 78/203, Haiti: A-B, $Q$ no. 3; D, F, undissected ơ ơ; C, S 79/606, Haiti, ९); G-M, Caribecandona ansa n. sp. (S 79/601, Haiti: G, $\sigma^{\circ}$ paratype; H-J, ९ holotype; K, o allotype; L-M, O no. 2); N-S, Caribecandona auricularia n. sp. (S 79/578, Haiti: N, ơ allotype; O-S, O* no. 2); T, Caribecandona sp. (S 79/527, Haiti, empty valve): A, M, right valves; B, L, T, left valves; C, H-J, undissected @ paratypes; D-G, K, N-S, undissected ơ paratypes; H, P, carapaces in dorsal view; $R$, carapace in posterior view; $S$, carapace in ventral view; $T$, left valve. 


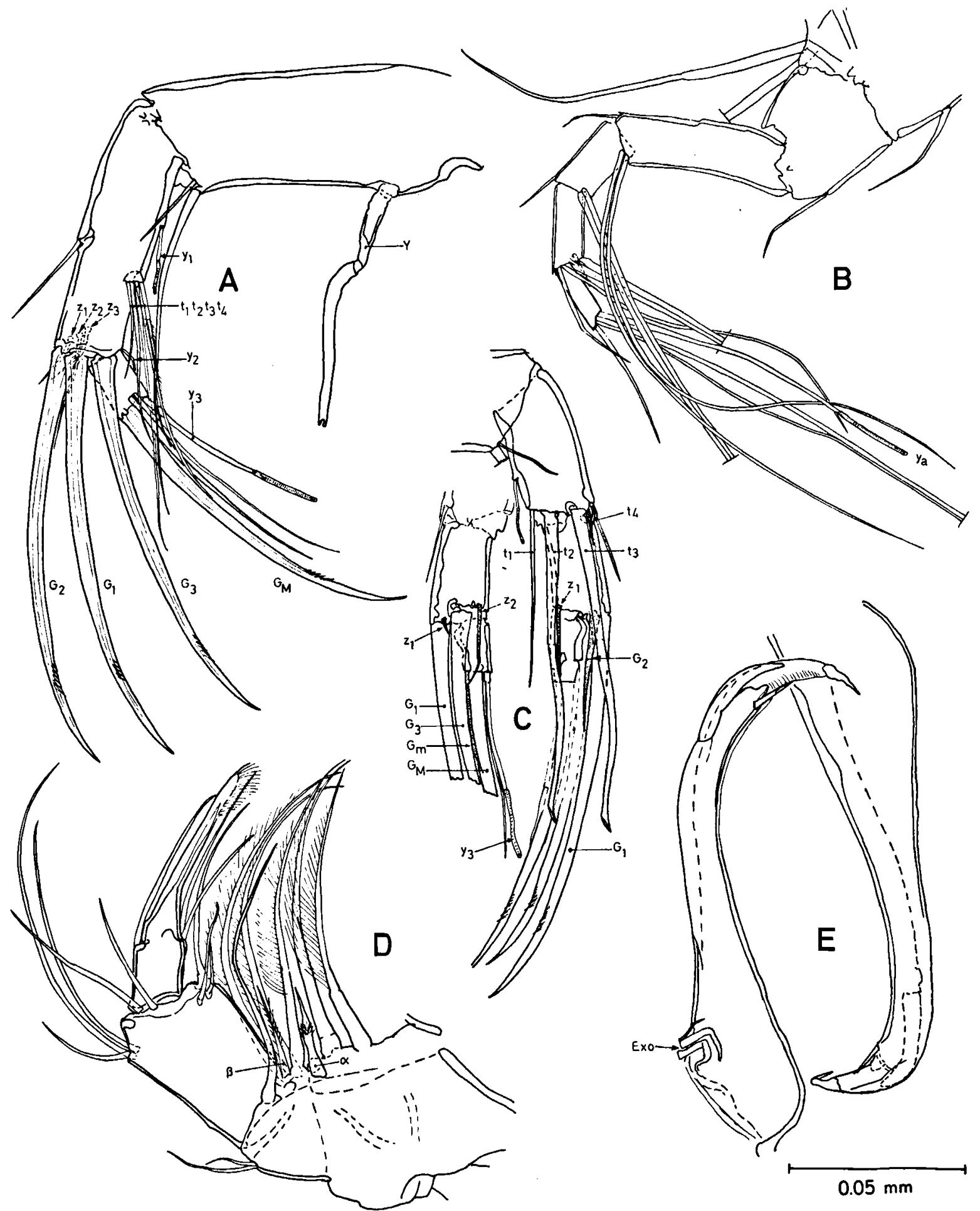

Fig. 9. Caribecandona trapezoidea n. gen., n. sp. (S 78/203, Haiti: A-B, ९ holotype; C, E, Ơ allotype; D, ९ no. 3): A, second antenna; B, antennule; C, distal part of second antenna, from interior and exterior side; D, mandibular palp; E, maxillar endopodites. 
fused with the terminal claw. Segment III is 2.5 times the length of segment IV.

Maxillula (Mxu) (fig. 10A):

Mxup I: Ex-3l-1m/II: D-2l(cs)-2m-2s/Mastic I: D-12m/II: D-8m(?)/III: In- $1 m(\mathrm{pu}), \quad$ D-4m$1 s(\mathrm{pu})-2 m(\mathrm{cs})$.

The claw-like setae of mastic 3 are smooth.

Maxilla (Max) (fig. 9E):

१: Pr: A-1s(a), In-1m(b:pu)-1s/Mastic: D-12s/Exo: $2 s(\mathrm{pu})-1 s / \mathrm{E}: \mathrm{D}-3 s$.

The chaetotaxy of both male and female maxillae is as in other Candoninae, they possess one ' $a$ ' seta and three exopodal setae. The male maxillar endopodites have changed in elongated, distorted claws. An exact description is given in the diagnosis of the genus. Because of the torsion, the proximal part of the endopodite seems to be wide at one side and narrow at the other. It seems to be hollow when viewed from the dorsal interior side. The position of the subterminal exterior claw is also difficult to see because of the torsion. In figs. 10 O-P, the distal part of the maxilla of Caribecandona auricularia $\mathrm{n}$. sp. is shown from different angles.

Thoracopod 1 (T 1) (fig. 10B):

Pr: A-1 $m /$ E I: A-1s/E II: A-1s/E III: A-2s/E IV: D-2s-1l(G:ser).

The proportional lengths of the segments I to IV and claw are: $6.3: 3.5: 2.7: 1: 10.2$.

Thoracopod 2 (T 2) (figs. 10C-D):

Pr: Ex-1l-1m, In-1l/E I: P-1 $m /$ E II: P-1s/E III: P-1s/E IV: D-1s(pu)-1 $m(\mathrm{pu})-1 l(\mathrm{pu})$.

The proportional lengths of $E$ I to IV are: 5.5: 2.7: 2.5: 1 .

Furca (Fu) \& furcal attachment (fuat) (figs. 10E-G):

The furca consists of a ramus and one serrate anterior claw. The posterior claw is reduced to a short spine-like seta, which is only slightly longer than seta $s_{\mathrm{a}}$. There is no seta $\mathrm{s}_{\mathrm{p}}$ present, as in the genus Candonopsis. $\mathrm{G}_{\mathrm{a}} / \mathrm{R}=1.0 ; \mathrm{G}_{\mathrm{p}} / \mathrm{G}_{\mathrm{a}}$ $=0.1$ and $\mathrm{s}_{\mathrm{a}} / \mathrm{G}_{\mathrm{a}}=0.06$.
The furcal attachment is simple in the male, with only one side branch. In the female there are three side branches, as in the other Candoninae described in this paper. The first side branch is bifurcate.

Copulatory organs (figs. 7B, 11B, E-F):

The female copulatory organ is rounded posteriorly. There are no other special characters.

The hemipenis of the male consists of three lobes, a flat distal, lateral lobe, ' $a_{1}$ ', with a rounded tip; a proximal pointed, flat lateral lobe, ' $a_{2}$ '; and the medial lobe ' $b$ ', which is more or less quadrangular, with a protruding distal part. The labyrinth is as in Candonopsis, which means that part ' $d_{4}$ ' is missing. The bursa copulatrix is surrounded by some strongly sclerified parts, especially one elongated pointed process ( $f$ ), which is connected proximally by other structures with a twisted more or less S-shaped, elongate structure (g), which might be homologous with part ' $M$ ' in the other Candoninae. The distal part of the copulatory tube is crumpled up and covered by a transparent granulated membranous structure, which can be seen best when the hemipenis is in erection, with the copulatory tube (ct) extending (fig. 11F).

The Zenker's organ contains seven whorls of spines. There seem to be four testicular lobes at the inner side of the valves.

Caribecandona auricularia n. sp.

(Figs. 7C-D, 8N-S, 10L-P, 11D, G-J)

Material. - Holotype: 1 female (ZMA Ost. 150.797). Allotype \& paratype: 2 dissected males (ZMA Ost. 150.798).

Type-locality: S 79/578, Haiti, well of Mrs. TisséCoriolan, at Dumonet, between Caiman and Debas, about $200 \mathrm{~m}$ of the "Trou Caiman", a large karst spring, Dépt. de l'Ouest $\left(18^{\circ} 38^{\prime} 58^{\prime \prime} \mathrm{N} 72^{\circ} 06^{\prime} 58^{\prime \prime} \mathrm{W}\right)$; well dug in sandy bottom; water table at $5.1 \mathrm{~m}$, water depth $0.9 \mathrm{~m}$; chlorinity $420 \mathrm{mg} / \mathrm{l}$; Cvetkov net; 21-XI-1979. Accompanying fauna: Cyclopidae, Phyllopoda, Anopsilana sp. (Isopoda), hadziid Amphipoda, Pyrgophorus (Gastropoda); Ostracoda: Chlamydotheca unispinosa, Physocypria sp.

The species was not found in any other sample. In one sample a carapace and a valve were found of a species 

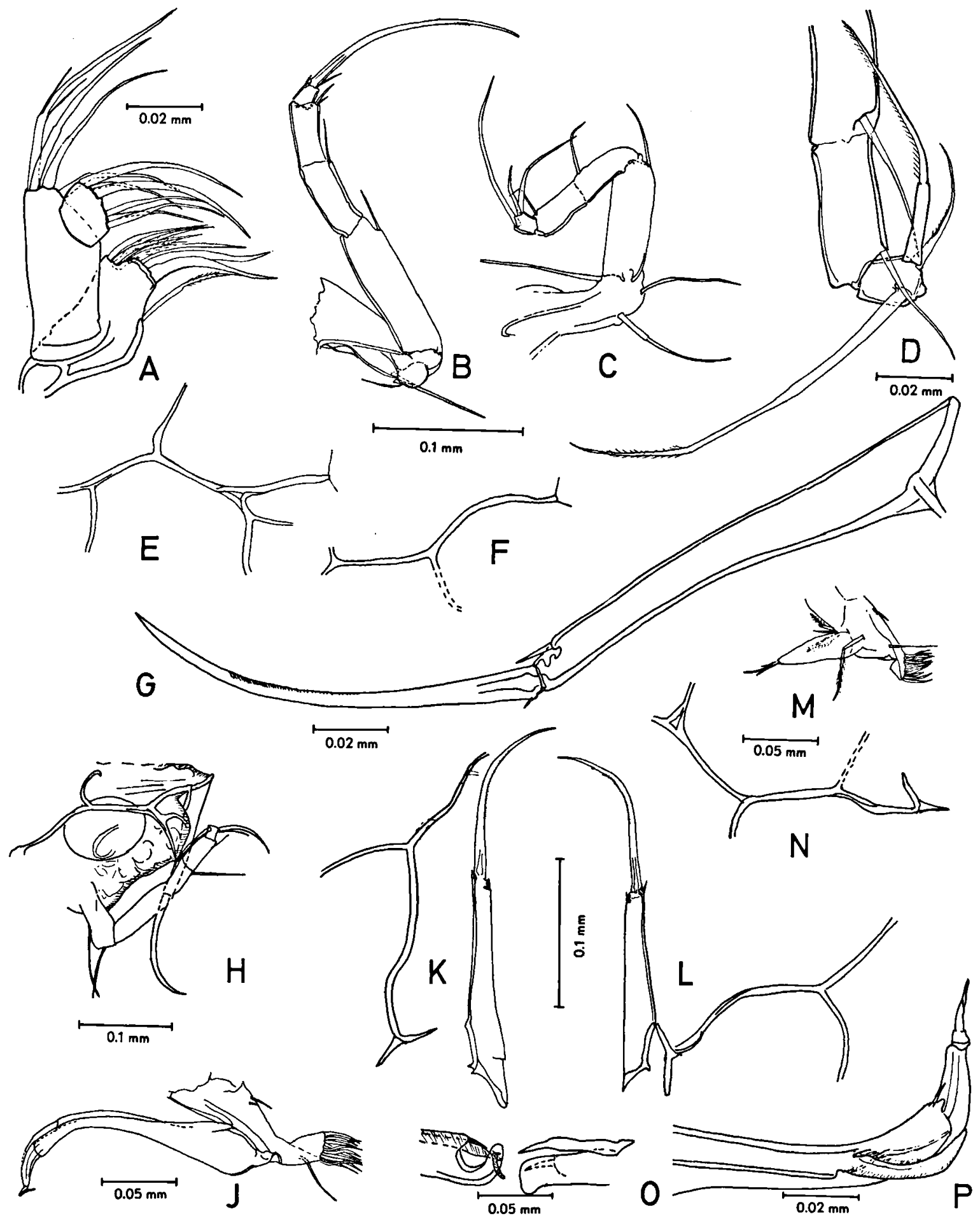

Fig. 10. A-G, Caribecandona trapezoidea n. gen., n. sp. (S 78/203, Haiti: A-B, D-E, G, $९$ holotype; C, F, o allotype); H-K, Caribecandona ansa n. sp. (S 79/601, Haiti: H, ९ holotype; J-K, O allotype); L-O, Caribecandona auricularia n. sp. (S 79/578, Haiti: L, P, O* allotype; M-N, \& holotype; O, O no. 2): A, maxillula; B, first thoracopod; C-D, second thoracopod with detail of distal part; E-F, furcal attachments; G, furca; H, posterior part of body; J, M, O-P, maxillae, and details of distal parts of endopodites; K-L, furcas with furcal attachments; $N$, furcal attachment. 
which looks like $C$. auricularia, but which is much larger (fig. 8T). It is therefore referred to as Caribecandona sp. This carapace and valve have been found in $\mathrm{S} 79 / 527$, the interstitial of the border of "Étang Saumâtre", only $25 \mathrm{~km}$ from $S 79 / 578$, in the same hydrogeographic region.

\section{Description}

Carapace (figs. 7C-D, 8N-S):

Most characteristics of the carapace are the same as in C. trapezoidea, especially the shape and structure of the right valve. The surface reticulation of the valves is also the same, as are the structure of the duplicature and the pore canals. However, the left valve possesses a rounded dorsal protuberance, or comb. The size of this protuberance seems to be variable, because it is different in the two males encountered (figs. 8N-O). Since only two males and one female, of which the left valve is destroyed, were found, this variation can only be established qualitatively.

The right valve of the female holotype measures $0.68 \times 0.37 \mathrm{~mm}$. The left valves of the males measure $0.68 \times 0.47$ and $0.71 \times$ $0.44 \mathrm{~mm}$, and the right valves $0.66 \times 0.38$ and $0.68 \times 0.37 \mathrm{~mm}$, respectively. The carapace of the Caribecandona sp. which was found in sample S $79 / 527$ measures $0.93 \times 0.60 \mathrm{~mm}$ for the left, and $0.91 \times 0.47 \mathrm{~mm}$ for the right valve, thus much larger (fig. 8T).

Appendages (figs. 10L-P):

The structure and chaetotaxy of all appendages, except for the hemipenis, are the same as in C. trapezoidea.

Hemipenis (figs. 11D, G-H):

The anterodistal part of the medial lobe (b) is less pointed and pronounced than in $C$. trapezoidea. The lateral lobe $\mathrm{a}_{2}$ is totally different from the corresponding part in $C$. trapezoidea. It is less independent from the other lobe $a_{1}$, shorter, less protruding and more blunted. The structure of the inner parts of the hemipenis, and of lobe $a_{1}$ is the same as in C. trapezoidea.

Etymology. - Auricularia means "like an ear", alluding to the "ear"-like process at the dorsal margin of the carapace.
Caribecandona ansa $n$. sp.

(Figs. 7E-F, 8H-M, 10H-K, 11A, C)

Material. - Holotype: 1 female (ZMA Ost. 150.800). Allotype \& paratypes: 2 dissected males, 1 aberrant male, 19 undissected males and females (ZMA Ost. 150.801).

Type-locality: S 79/601, Haiti, well of Gaby Gabriel, at Dessalines (Street Jacques Ier), Dépt. de l'Artibonite $\left(19^{\circ} 15^{\prime} 36^{\prime \prime} \mathrm{N} 72^{\circ} 31^{\prime} 01^{\prime \prime} \mathrm{W}\right)$; well dug in sediments of sand and gravel, not covered, walled-in to certain height; water table at $8 \mathrm{~m}$, water depth $3 \mathrm{~m}$; Cvetkov net; chlorinity $140 \mathrm{mg} / \mathrm{l} ; 23-\mathrm{XI}-1979$. Accompanying fauna: Hirudinea, Cyclopidae, Thermosbaenacea, hadziid Amphipoda, Hydracarina, Insecta, Lamellibranchia. No other Ostracoda.

This species was only encountered in the type-locality.

\section{Description}

Carapace (figs. 7E-F, 8G-M):

Most characteristics of the carapace are just as in both other species. Here too, as in $C$. auricularia, the only real difference is the presence of a dorsal protuberance, or comb, at the dorsal margin of the left valve, which runs from the anterior to the posterior border. The upper margin of this comb is practically straight. As in C. auricularia, the size of this protuberance seems to be variable which can be seen from the variation in the height of the carapace, compared with the length. One male specimen was found in which the dorsal protuberance was practically absent. Only a broad dorsal ridge remains in this specimen (fig. 8G). However, the structure of the hemipenis was the same as in normal specimens of $C$. ansa.

The dimensions of the left and right valves of the female holotype are: $0.69 \times 0.44$ and 0.67 $\times 0.35 \mathrm{~mm}$, respectively, and of the male allotype $0.71 \times 0.48$ and $0.69 \times 0.41 \mathrm{~mm}$, respectively. It was impossible to ascertain the sex of the remaining specimens without dissection. However, there seems to be no difference in size between males and females. The mean length of the specimens is $0.67 \pm 0.02 \mathrm{~mm}(n$ $=19)$, and the mean height $0.43 \pm 0.02 \mathrm{~mm}(n$ = 18). Perhaps males are somewhat larger, because the four specimens recognized as males ranged from $0.69-0.71 \mathrm{~mm}$ in length. In the right valve of the male, the highest part seems to be posterior of the middle at two-thirds of the 

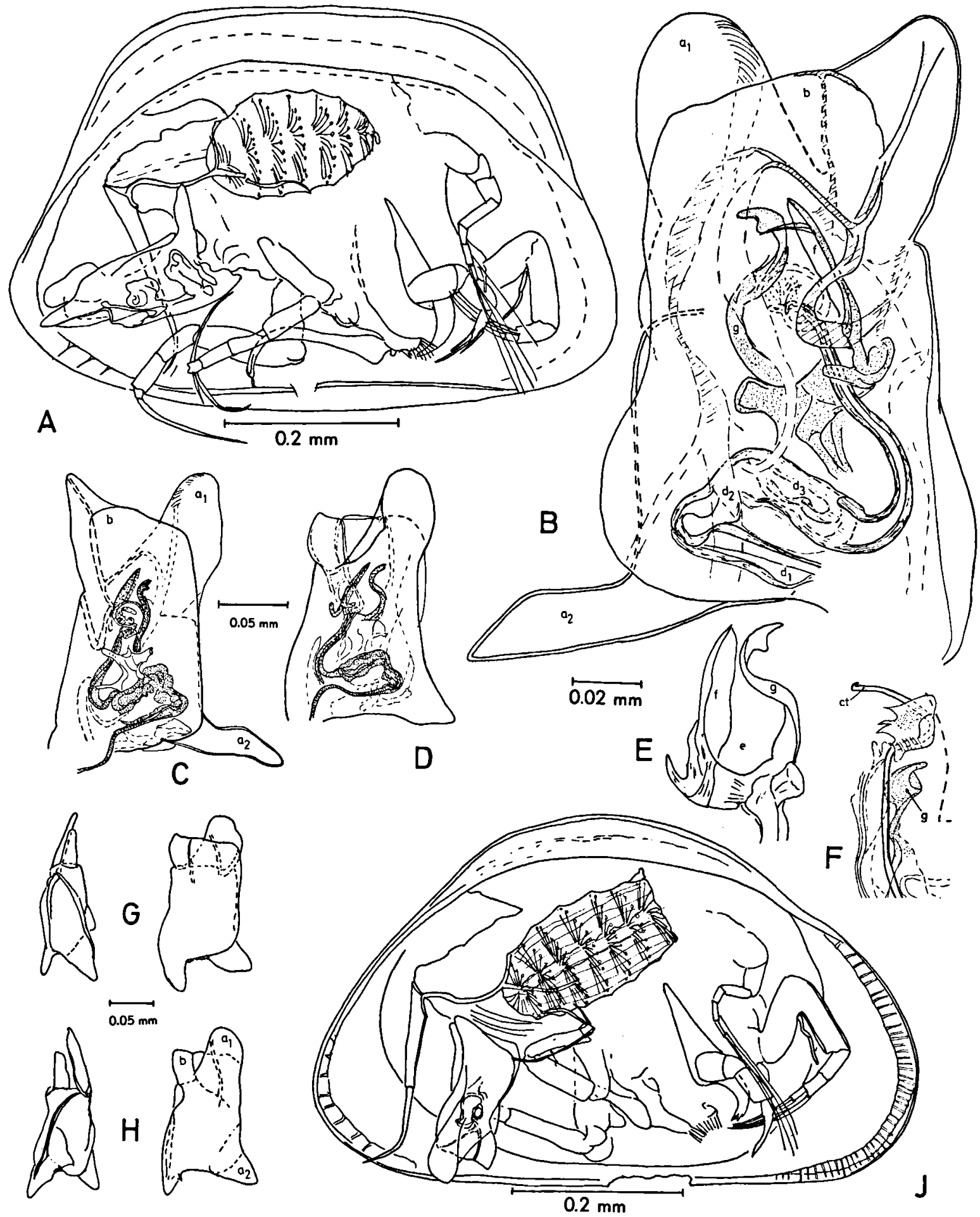

Fig. 11. A, C, Caribecandona ansa n. sp. (S 79/601, Haiti, o allotype); B, E-F, Caribecandona trapezoidea n. gen., n. sp. (S 78/203, Haiti, ơ allotype); D, G-J, Caribecandona auricularia n. sp. (S 79/578, Haiti: D, o allotype; G-J, o no. 2): A, J, left valve with undissected animal; B, D, right hemipenis; C, left hemipenis; E, detail of sclerified parts of bursa copulatrix; F, copulatory tube and part of bursa copulatrix in partial erection; G, left hemipenis in dorsal and laterointerior view; $\mathrm{H}$, right hemipenis in ventral and lateroexterior view. (For explanation see text.) 
length, while in the female the dorsal margin is more or less parallel with the ventral margin.

Appendages (figs. 10H-K):

The structure and chaetotaxy of all appendages, except for the hemipenis, are the same as in both other species.

Hemipenis (fig. 11C):

The anterodistal part of the medial lobe $b$ is more pointed, and lobe $a_{2}$ is more elongated than in $C$. trapezoidea. The other internal parts, and lobe $a_{1}$, are similar to those of the other two species. The overall structure of the hemipenis shows more resemblance to that of $C$. trapezoidea, than to that of $C$. auricularia.

Etymology. - From the Latin ansa, meaning handle, alluding to the dorsal protuberance of the carapace, which has the appearance of a handle.

\section{COMPARATIVE REMARKS ABOUT THE CARIBECANDONA SPECIES}

The fact that most of the internal characteristics of the three species are the same, indicates that they are very closely related. The only structural differences are the shape of the dorsal protuberance of the left valve, which is practically absent in $C$. trapezoidea, rounded in $C$. auricularia, and more elongated with a straight upper margin in $C$. ansa; and the shape of lobes $b$ and $a_{2}$ in the hemipenis. The shape and size of the dorsal margin or protuberance seems to be very variable within the three species. Considering the characteristics of the hemipenis, $C$. trapezoidea and $C$. ansa have more affinities with each other than with $C$. auricularia.

\section{Ecology and distribution of Caribecandona}

Only two samples containing many specimens of $C$. trapezoidea were found. In the other samples, the species is represented only by one or two specimens. The species has always been found in wells, covered as well as open, dug out mostly in a sandy or sedimental bottom. In most samples it was accompanied by epigean ostracod species, and other epigean animal groups, but also by hypogean animals, like Thermosbaenacea, Harpacticoidea, prawns of the genus Typhlatya, cirolanid isopods of the genus Anopsilana, and hadziid amphipods. The ostracod species most commonly found in the samples were: Chlamydotheca unispinosa and Strandesia stocki, two epigean species, very common in Haiti.

Only three specimens of $C$. auricularia were found in a well dug in sandy soil, with a chlorinity of $420 \mathrm{mg} / \mathrm{l}$. The species was accompanied by blind Amphipoda, specimens of Anopsilana sp., and epigean fauna, including Chlamydotheca unispinosa and Physocypria sp. (Ostracoda).

C. ansa was found in only one well, dug in sediments, with a chlorinity of $140 \mathrm{mg} / \mathrm{l}$. It was accompanied by Thermosbaenacea, hadziid Amphipoda, and epigean fauna, but no Ostracoda.

A carapace and a valve of Caribecandona sp. were found in the interstitial on the border of the Étang Saumâtre.

The fact that the three species of Caribecandona were found only in wells, often accompanied by hypogean fauna, especially when abundant, seems to point to a subterranean way of life. The fact that most wells were dug in sand or other sediments suggests that the species are interstitial. Further evidence of an interstitial and stygobiont way of life is found in morphological characteristics, like the hyper-development of the aesthetascs $\mathrm{Y}$ and $\mathrm{y}_{3}$ of the second antenna, and the reduction of segments and setae on some of the appendages. The species are small, (about $0.7 \mathrm{~mm}$ ), but not as small as the species from Venezuela described in the sequel $(0.4$ $\mathrm{mm})$.

C. trapezoidea was found in different hydrogeographical areas, on both sides of the Neiba plain, a plain connecting the southwestern part of Haiti with the rest of the island, which was submerged during high sea levels in the Pliocene, and probably also in the Pleistocene (Pregill \& Olson, 1981). This seems to indicate that the species already existed before the flooding of the plain. 
C. ansa has been found only once, in the central part of Haiti (fig. 12, no. 601), in a hydrogeographical region just north of the most northern locality where $C$. trapezoidea has been encountered, though only at a distance of 25 $\mathrm{km}$.

C. auricularia has been found in one of the hydrogeographical areas where $C$. trapezoidea also occurs, near the north coast of the Étang Saumâtre (fig. 12, no. 578). The valve and carapace of Caribecandona sp. were found at the southern border of this lake.

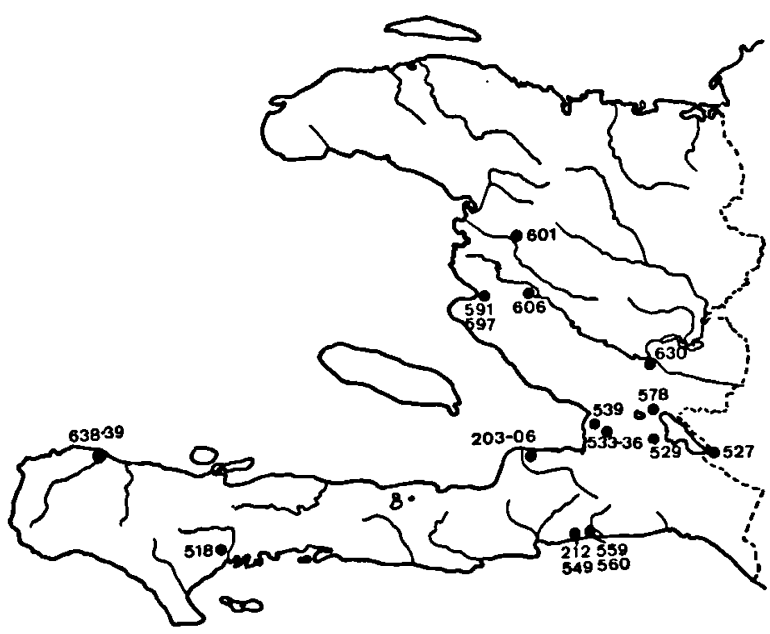

Fig. 12. Map of Haiti, with stations sampled during the Amsterdam Expeditions to the West Indian Islands in 1978 and 1979. Main rivers are indicated. Only stations where species of the subfamily Candoninae were found are shown.

It seems that the species of Caribecandona in Haiti are not separated by geographical barriers, only $C$. ansa could be hydrogeographically isolated from $C$. trapezoidea (if the latter species will not be encountered in the northern parts of Haiti, which have not been sampled extensively). So at least three, and probably four, very closely related species have developed in a restricted area, in contrast to the other Candoninae and Cypridinae in the West Indies, which are represented by relatively fewer species in each island, or with a much wider distribution (Broodbakker, 1982; 1983a, b, c). The same phenomenon is found in species of Metacypris (Elpidium) from Cuba, and in other animal groups like the Drosophilidae of Hawaii. Danielopol (1975) described three new species of Elpidium from bromeliads in Cuba. The three species are very closely related and differ only in details of the structure of hemipenis and valves. It seems that differences in the structure of the genital organs insure sexual isolation, because of their sensual function. The interspecific differences in the structure of the hemipenis were always accompanied by differences in the structure of the valves. The same phenomenon is found in the species of Caribecandona from Haiti, which also differ only in the structure of the valves, especially the shape of the dorsal protuberance, and the structure of the hemipenal lobes.

An extreme example of species richness because of sexual selection, is the family Drosophilidae. It is probable that the 508 species which are now known from the Hawaiian islands are all descendants of a single ancestral individual (Kaneshiro, 1983). The different species have arisen from differences in the structure of male genitalia, or from different mating behaviour. It seems that in Caribecandona as well as in Elpidium and the Drosophilidae, sexual selection has been the most important factor for the evolution of new species.

Since isolation is achieved sooner in hypogean species, because of their limited capacities for dispersion, this could be an explanation for the evolution of four species of Caribecandona in a restricted area, by way of subsequent isolation of populations of an ancestral species, which could be $C$. trapezoidea, since this species has the widest distribution.

\section{A NEW HYPOGEAN GENUS OF CANDONINAE FROM VENEZUELA}

During the Amsterdam Expeditions of 1982, we paid a visit to the small town of Calabozo, in the Estado Guárico in Venezuela, some $180 \mathrm{~km}$ south of Caracas. In this town many wells have been dug, mainly in breccias, which seem to be old river sediments. In one of these wells, about fifty specimens of a very small ostracod were 
found, together with specimens of a new hypogean isopod, belonging to the new suborder Calabozoidea. In the other wells sampled in Calabozo no more ostracods of this species were found, while in many of these wells Calabozoa pellucida Van Lieshout, 1983, and Bogidiella neotropica Ruffo, 1952, a hypogean amphipod, were found. The small ostracods turned out to belong to a new genus of Candoninae, because of many special characters.

\section{Danielocandona $\mathrm{n}$. gen.}

Type-species: Danielocandona lieshoutae n. sp. (by monotypy).

The genus has the following unique characteristics compared with the other Candoninae:

(1) The second segment of the maxillular palp is elongated with only one serrate claw-like seta and two flexible setae.

(2) The furca possesses only one distal claw, which is fused with the ramus. The other setae have disappeared.

(3) The second and third endopodal segments of the walking leg ( $\mathrm{T}$ 1) are fused, and the former second segment does not carry a seta.

(4) The distal part of the copulatory tube in the hemipenis of the male is bifid.

The carapace shape is trapezoidal, like in Caribecandona, Mixtacandona, and the other species mentioned in this article. The carapace is very small, about $0.4 \mathrm{~mm}$, as in Nannocandona faba Ekman, 1914 (epigean), and Pseudocandona triquetra (Klie, 1936) (hypogean), thus the species is one of the smallest Candoninae.

The first antenna has the segments III + IV and V + VI fused, like in the genus Nannocandona Ekman, 1914.

The clasping organs of the male maxillae are symmetrical with thin distal fingers, as in the genus Mixtacandona.

The walking leg is as in Phreatocandona motasi Danielopol, 1978 (fig. 2, p. 24), with a very long seta on the third endopodal segment and without setae on the protopodite and the first endopodal segment. This last characteristic it also shares with some species of the genus Mixtacandona.

The second and third endopodal segments of the cleaning leg ( $\mathrm{T}$ 2) are fused, and the fourth segment bears only one long seta, as in the genus Pseudocandona. Of the two remaining small setae of segment four, one is very short, as in some species of the genus Mixtacandona. The protopodite does not bear an interior seta as in the genus Terrestricandona Danielopol \& Betsch, 1980.

The Zenker's organ possesses six whorls of spines, as in Pseudocandona similampadis Danielopol, 1978, and the Pseudocandona species from Lake Baikal.

The hemipenis has a distally rounded lateral lobe, as in the genera Pseudocandona, Caribecandona and Mixtacandona. The bursa copulatrix is open, as in some Mixtacandona species. Part $\mathrm{d}_{4}$ of the labyrinth is absent, as in the genera Candonopsis, Caribecandona and Mixtacandona. There seem to be three testicular lobes in the valves, as in the genus Mixtacandona.

Etymology. - The name of the genus is a contraction of part of the name of Dr. D. L. Danielopol and of the generic name Candona, because the new genus belongs to the subfamily Candoninae. The genus is named after Dr. Danielopol in recognition of his large contribution to the knowledge of the taxonomy and evolution of hypogean Candoninae. Furthermore, the author acknowledges his great help during this study.

\section{Danielocandona lieshoutae n. sp.}

(Figs. 13, 14)

Material. - Holotype: 1 female (ZMA Ost. 150.792). Allotype: 1 male, paratypes: 2 males and 2 females dissected, and about 50 undissected males and females (ZMA Ost. 150.793).

Type-locality: S 82/557, Venezuela, Edo. Guárico, round open well of Nancy de Venega, Calabozo, quarter Misión $\left(8^{\circ} 55^{\prime} 17^{\prime \prime} \mathrm{N} 67^{\circ} 27^{\prime} 00^{\prime \prime} \mathrm{W}\right)$; diam. $2 \mathrm{~m}$. water table at 2.5 $\mathrm{m}$, water depth $0.6 \mathrm{~m}$; dug out in breccias, upper part cemented; chlorinity $50 \mathrm{mg} / \mathrm{l} ; 10$-III-1982. Accompanying fauna: Oligochaeta, Harpacticoidea, Calabozoa pellucida (Isopoda), Insecta, Gastropoda. 

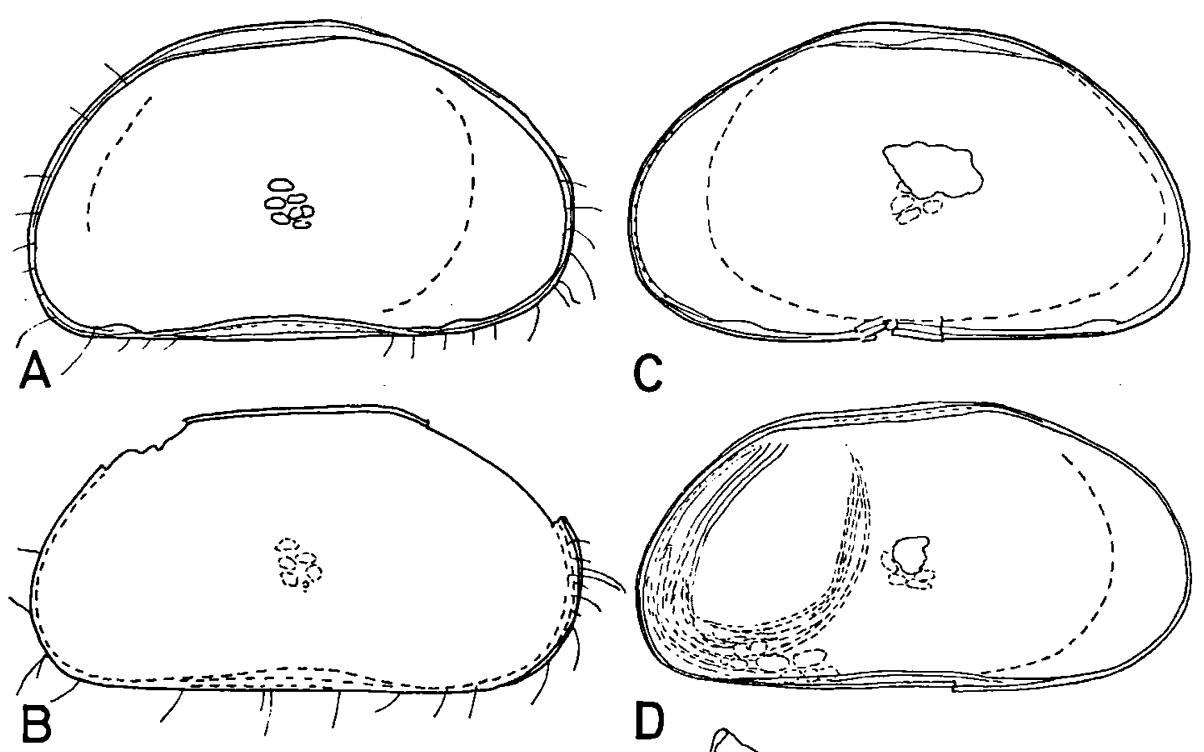

C

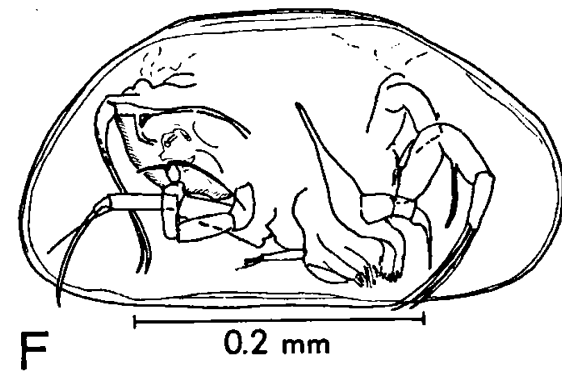

$F$
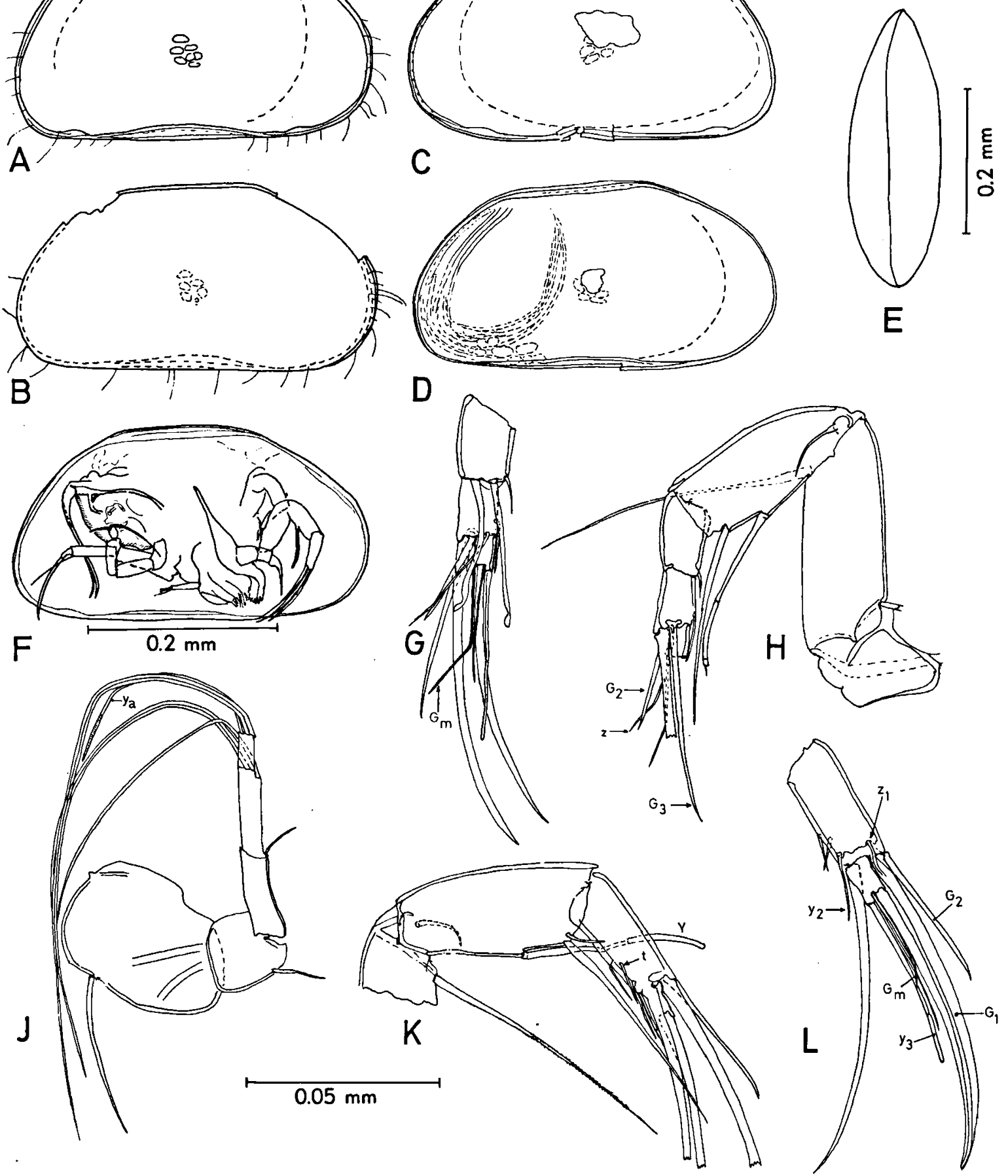

Fig. 13. Danielocandona lieshoutae n. gen., n. sp. (S 82/557, Calabozo, Venezuela, Edo. Guárico: A-B, F, J-L, ९ holotype; C-D, G-H, O allotype): A, C, left valves; B, D, right valves; E, carapace in dorsal view; F, undissected animal in left valve; G-H, K-L, details of second antenna in interior and exterior view; $\mathrm{J}$, antennule. 


\section{Description}

Carapace (figs. 13A-F):

The carapace has a rounded trapezoidal shape. In dorsal view greatest width at $35-50 \%$ of the length, being about $35 \%$ of the length. Greatest height in front of the middle at $60-65 \%$ of the length, being $50-60 \%$ of the length. Surface densely punctate, and sparsely hairy. Muscle scars as typical of the Candoninae. Carapace whitish transparent. Left valve larger than and overlapping the right valve at all sides. Dorsal margin straight but sloping slightly in posteroventral direction. The dorsal ridge is broader in the left valve. The dorsal margin passes with angles of about $30^{\circ}$ in the broadly rounded anterior and posterior margins. Ventral margin straight, the inner margin sinuous in the middle. In the left valve there are two small rounded protuberances at the inner posteroventral and anteroventral sides. Marginal pore canals indistinct. Duplicature broader anteriorly than posteriorly, ventrally and dorsally practically absent. There are only minor differences between males and females.

Carapace length varies for females and males from 0.37 to $0.40 \mathrm{~mm}$. The mean dimensions of the carapace are: $0.38 \times 0.21 \mathrm{~mm}$ for both males and females (both: $n=10$, S.D. = 0.01).

Since the species is very small it is possible that some small setae have been overlooked.

Antennule (A 1) (fig. 13J):

I: A-1l/II: A-1 $m /(\mathrm{III}+\mathrm{IV}): \quad \mathrm{A}-1 s /(\mathrm{V}+\mathrm{VI})$ : A-3l/VII: D-2l-1 $l\left(\mathrm{y}_{\mathrm{a}}\right)$.

Segments III + IV and segments $\mathrm{V}+\mathrm{VI}$ are fused, therefore $1 / 2$ (III + IV) is used as reference for the chaetotaxy system. The two posterior setae and one anterior seta of the first segment have disappeared. The seta of the former third segment, the long setae of the former fourth segment, and the setae of the former fifth segment have likewise disappeared. At the former sixth segment three long setae, and at the former seventh segment two long setae have remained. The aesthetasc $y_{a}$ is relatively long, being nearly three times as long as segment III + IV.
Second antenna (A 2) (figs. 13G-H, K-L):

Pr: P-1l/Exo: 1s/E I: P-Y-1l-1s/........../E IV: D- $1 m-1 m\left(\mathrm{G}_{\mathrm{m}}\right)-\mathrm{y}_{3}-1 l\left(\mathrm{G}_{\mathrm{M}}\right)$.

Q : $\mathrm{E}(\mathrm{II}+\mathrm{III}): \quad \mathrm{P}-1 s\left(\mathrm{y}_{1}\right)-1 s(\mathrm{t}), \quad \mathrm{D}-1 s\left(\mathrm{y}_{2}\right)-1 s(\mathrm{z})-$ $2 l\left(\mathrm{G}_{1,3}\right)-1 m\left(\mathrm{G}_{2}\right)$.

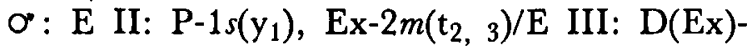
$1 m(\mathrm{z})-1 m\left(\mathrm{G}_{2}: \mathrm{cs}\right), \mathrm{D}(\mathrm{In})-1 l\left(\mathrm{G}_{1}\right)-1 m\left(\mathrm{G}_{3}: \mathrm{cs}\right)$.

In both male and female $G_{2}$ is reduced to a claw-like seta, and $y_{1}, y_{2}$ and $G_{m}$ look like normal setae. There is only one $z$ seta visible. Only one $t$ seta is visible in the female, whereas in the male there are two male $t$ setae like in most other Candoninae. $G_{3}$ is slender and claw-like in both sexes. The exopodite seems to consist of only one small seta. Segments E(II + III) are fused in the female and divided in the male. The aesthetascs $Y$ and $y_{3}$ are strongly developed, which indicates a subterranean mode of life.

Mandibular palp (Mdp) (fig. 14A):

I: In- $1 m\left(\mathrm{~S}_{1}: \mathrm{pu}\right)-1 s\left(\mathrm{~S}_{2}: \mathrm{pu}\right)-\alpha / \mathrm{II}: \quad \operatorname{In}-3 m-1 m(\beta) /$ III: $\mathrm{Ex}-1 s-1 m$, In-1s-1m/IV: (fused with: $1 m$ :ser) In-1s, Ex-1s.

As in A 1 and A 2, many setae have disappeared, exterior as well as interior setae. Seta $\beta$ looks like a normal seta. The terminal seta is fused with the fourth segment and has a bladelike appearance.

The mandible possesses seven terminal teeth, three plumose setae anterodistally, one longer seta anteriorly, and two small plumose setae posterodistally, as in the other Candoninae.

Maxillula (Mxu) (fig. 14B):

Mxup I: Ex-2m/II: D-1s(cs:2ser))-2s/Mastic I: D-4s/II: D-6s/III: D-2s(cs:2ser)-4s.

As in the other limbs, many setae have disappeared. Mxup II bears only three setae instead of six, one of which is claw-like and serrate. The third masticatory process bears two serrate claw-like setae as in many other Candoninae and Cypridinae. All other setae are simple and there are only few in comparison with other species.

Maxilla (Max) (fig. 14C):

The masticatory process seems to bear six setae, 

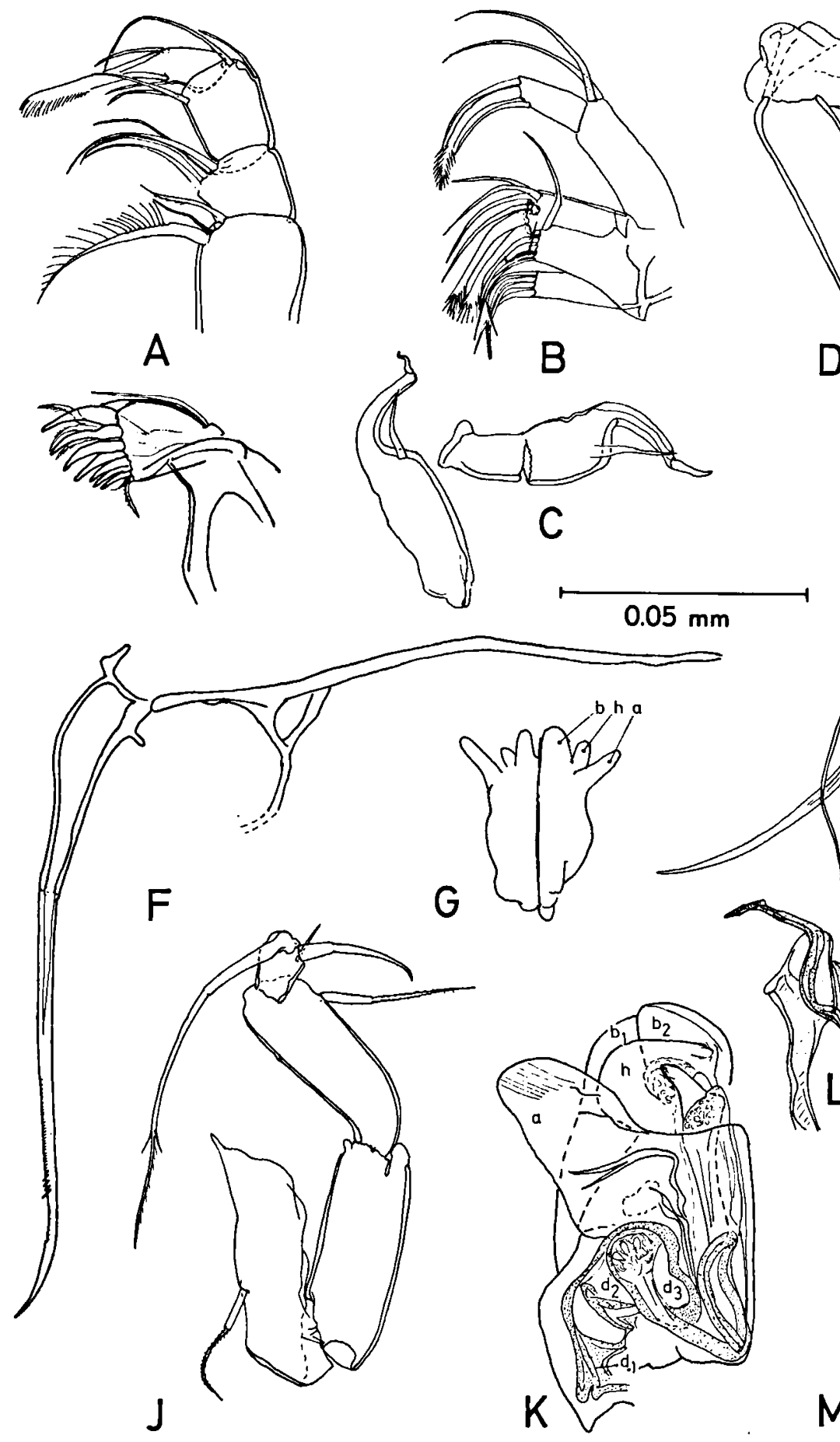

Fig. 14. Danielocandona lieshoutae n. gen., n. sp. (S 82/557, Calabozo, Venezuela, Edo. Guárico: A-C, E, G, J, L, ơ no 3; $\mathrm{D}, \mathrm{H}, \mathrm{M}, \sigma^{\circ}$ allotype; F, $\odot$ holotype; K, $\sigma^{\circ}$ no. 2): A, mandibular palp and distal part of mandible; B, maxillula; C, maxillar endopodites; D, first thoracopod; E, furca; F, furca with furcal attachment; G, hemipenis in dorsal view; H, Zenker's organ; J, second thoracopod; K, right hemipenis; L, detail of copulatory tube with distal parts of bursa copulatrix; M, hemipenis in erection. (For explanation see text.) 
and the endopodite in the female three short setae. No other setae could be found in the maxillae of the specimens dissected. Neither exopodal setae, nor one of the $a, b$, or c setae were found.

The endopodites in the male are transformed into symmetrical clasping organs, with thin distal tips and long flexible second teeth (fig. 14C).

Thoracopod 1 (T 1) (fig. 14D):

$\mathrm{E}(\mathrm{II}+\mathrm{III}): \mathrm{D}(\mathrm{A})-1 l-1 s / \mathrm{E} \mathrm{IV}: \mathrm{D}-2 s-1 l(\mathrm{G})$.

The second and third endopodite are fused.

The setae of Pr, E I and the former E II have disappeared. One of the setae of E(II + III) is very long, being $90 \%$ of the length of the terminal claw, probably this seta has a sensory function. $\mathrm{E} I$ is about as long as $\mathrm{E}(\mathrm{II}+\mathrm{III})$, $\mathrm{E} I V$ is nearly $30 \%$ of the length of $\mathrm{E} I$.

Thoracopod 2 (T 2) (fig. 14J):

Pr: $\quad \mathrm{Ex}-1 m(\mathrm{pu}) / \mathrm{E}(\mathrm{II}+\mathrm{III}): \quad \mathrm{P}-1 m(\mathrm{pu}) / \mathrm{E} \quad \mathrm{IV}$ :

D- $1 l(\mathrm{pu})-1 m(\mathrm{cs})-1 s$.

The protopodite is devoid of one exterior and one interior seta. One of the minor setae of $\mathrm{E}$ IV is very short. E(II + III) and E I have about the same length.

Furca $(\mathrm{Fu})$ \& furcal attachment (Fuat) (figs. 14E-F):

The furca is whip-like, as in the species of the subfamily Cypridopsinae. All setae are absent, the anterior claw is fused with the ramus, the point of fusion being visible at one-third of the length. The terminal part of the furca is serrate for about $40 \%$ of its length. No trace is visible of the posterior claw.

The furcal attachment is straight and simple with an eye-like loop and short side branch at about one-quarter of the length of the main branch (fig. 14F).

Copulatory organs (figs. 13F, 14G-H, K-L): The female copulatory organs have no special characters. The posterior part of the body is flatly rounded. Ovigerous females carried only two or three eggs, another indication of a subterranean life style (Danielopol, 1980b).
The Zenker's organ in the male has six whorls of spines, unlike most other Candoninae, which have seven.

The peniferum of the male hemipenis consists of three lobes, a distally rounded lateral one (a), and two distal lobes (b, h), of which one (b) seems to be folded. Both lobes are distally blunted, but when viewed from the ventral or dorsal side they are rounded (fig. 14G). The labyrinth is primitive, part $d_{4}$ is missing, while part $d_{3}$ looks simple. It is shown extended in fig. 14L. The bursa copulatrix is open, and surrounded by weakly sclerotized, elongate rods, which are difficult to recognize separately, in particular since the copulatory tube (ct) is coiled terminally. The distal part of the tube is bifurcate, as can be seen clearly in fig. 14M. Some of the distal internal parts and the copulatory tube are shown in fig. $14 \mathrm{~L}$.

There seem to be three testicular lobes in the valves.

Taxonomic remarks. - Most remarks and comparison with other species and genera have already been made in the description of the genus. There is no clear or close relation with any of the known genera. The species especially attracts attention because of the strong reduction of setae and segments. Many of the setae which are present in other Candoninae as well as in Cypridinae have disappeared.

Etymology. - The species is named in honour of Mrs. Sylvia van Lieshout, who took part in the Venezuelan expedition of 1982, and who described the new suborder of the Calabozoidea.

Ecology and zoogeography. - The species was encountered only in one well, dug in alluvial deposits of probable Quaternary origin. These deposits consist of conglomerates of gravel and sand. The sand is coloured redbrown by a large amount of iron. The fact that the species was accompanied by the subterranean, probably interstitial, isopod Calabozoa pellucida, is an indication that the well is connected with a phreatic system of considerable 
size, since $C$. pellucida has been found in many other wells around Calabozo.

There are several reasons to assume the species to be hypogean and interstitial: (1) the small size of the carapace; (2) the strong reduction of setae and segments; (3) the strong development of the aesthetascs $\mathrm{Y}$ and $\mathrm{y}_{3}$ of the second antenna and $\mathrm{y}_{\mathrm{a}}$ of the antennula; (4) the low number of eggs in ovigerous females.

No clear relation can be found with any other genus of the subfamily Candoninae. It is possible that Danielocandona is a relict of an old group of Candoninae species, which has adapted to a hypogean, interstitial mode of life. The same seems to hold true for the isopod Calabozoa which, like Danielocandona, seems to be intermediary between other groups of Isopoda (Van Lieshout, 1983). Both Calabozoa and Danielocandona probably belong to a very old stock of species. It is possible that the species were forced into the groundwater because of the climat getting hotter. However, this remains speculative.

\section{ORIGIN AND PHYLOGENETIC TRENDS OF} CARIBECANDONA AND DANIELOCANDONA

The trend towards development of trapezoidal and triangular carapaces has been repeated several times, within Caribecandona, Danielocandona and some Candonopsis species, but also in some Candona species from Lake Ohrid, species of the genus Mixtacandona Klie, 1933 and Pseudocandona from subterranean habitats in Europe, and in species of Baikalocandona Mazepova, 1976 and Pseudocandona from Lake Baikal. Most other Candoninae have a more elongated and/or rounded carapace.

One of the trapezoidal Candonopsis species is C. putealis Klie, 1932 from a spring in Java (Indonesia), which is supposed to be hypogean because of long $Y$ and $y_{3}$ aesthetascs and the absence of an eye. However, in the structure of the appendages it is like the elongated species of Candonopsis. The hemipenis has an acuminate lobe ' $a$ ' and a medial short lobe ' $b$ ', as in other Candonopsis species. The clasping organs of the male maxillae, and the hook on the posterior claw of the furca, are likewise as in other Candonopsis (Klie, 1932; Danielopol, 1980a).

The two other, more or less triangular, Ciandonopsis species are: $C$. thienemanni and $C$. trichota, both described by Schäfer, 1945, from groundwater habitats in Greece. These two species have some morphological characteristics in common with Caribecandona. In these species the segments III and IV of the mandibular palp have a length ratio of 1.5: 1. The furcal claws do not possess hooks. However, in these species there is only one lobe ' $a$ ' in the hemipenis, the length/width ratio of Mdp: IV is 3.0: 1 , and the clasping organs of the maxillae are long and without protuberances, characteristics found in other Candonopsis species as well (Schäfer, 1945).

The species of Pseudocandona from Lake Baikal have trapezoidal carapaces, but the internal characters are more like those in other Pseudocandona species, and not like those in Caribecandona and Danielocandona (Bronstein, 1947). The same holds true for the triangular and trapezoidal Candona species from Lake Ohrid, which are internally like the other Candona species. The species described by Mazepova (1976) as Baikalocandona are intermediary between Candona and Pseudocandona. The carapaces of some of these species are strikingly similar to those of Caribecandona, but the structure of the male maxillae and furca are totally different, and more as in the other genera mentioned. Mazepova (1976) considers the genera Pseudocandona and Baikalocandona as unsuccessful lateral branches of the Candoninae, and assumes the Baikal species belonging to these genera to be of relict origin.

Danielopol (1978) did not find any phylogenetical affinities, when comparing the trapezoidal and triangular Candoninae species from European groundwater, with some species of this type from Lake Baikal and Ohrid. He is of the opinion that the trend for developing trapezoidal carapaces has developed independently in different parts of the world. The differences in the structure of the limbs between the geographically different groups seem to indicate that this hypothesis could be correct, and 
that the similarity in carapace shape is some sort of convergent evolution. The trend for the development of this type of carapaces seems to be stronger in relatively stable habitats, like subterranean systems and otherwise physically and biologically stable habitats, like Lakes Baikal and Ohrid, as hypothesized by Danielopol (1980) for Candoninae with elongate carapaces with a pointed posterior.

It seems that most of these trapezoidal Candoninae are remnants, or derived from remnants, of several Tertiary groups of Candoninae, which do not have a strong phylogenetic relationship with each other. In all groups the carapace developed or preserved a triangular or trapezoidal form.

In the West Indies this old group only survived in hypogean habitats, and was replaced in epigean habitats by "modern" elongate Candoninae, and by Cypridinae and Cypridopsinae. The connection between the species from Venezuela and those of Haiti must have been broken since a long time, because both genera are fairly different. The affinities between the species of Caribecandona from Cuba and Haiti are much stronger, but nevertheless both subgenera are clearly different.

The fact that this type of Candoninae is only present in the islands Hispaniola and Cuba, which are both possibly fragments of an old continental plate, and in the mainland of Venezuela, together with a probably relict species of isopod, is another argument for the assumption that these species are relicts of an old Candoninae fauna. The islands of Puerto Rico and Jamaica have not been sampled extensively enough to draw any conclusions about the possible occurrence of this type of Candoninae in these islands. In all other smaller islands of the West Indies no interstitial or hypogean ostracod species appear to have evolved, which seems to indicate that these islands are much younger, and could not recrute interstitial freshwater species from this old stock, since by then the ancestral forms were probably extinct. It is also possible that the groundwater species from Haiti, Cuba, and Venezuela have migrated into the groundwater because of the arid, hot climates which have occurred, especially in the Pleistocene (Pregill \& Olson, 1981). The epigean representatives of this old group could have become extinct because of the changes in climate and the competition with the younger groups of Cypridinae and Cypridopsinae (Cyprettinae).

\section{ACKNOWLEDGEMENTS}

In the first place I have to thank Dr. Dan L. Danielopol for all the help he gave in describing the new genera, the comparison with other Candoninae, and the interpretation of the characteristics of each species. My stay with him in the Institut für Limnologie in Mondsee, Austria, has been indispensable for the realization of this article. Furthermore, I would like to thank Prof. Dr. J. H. Stock, Dr. L. Botosaneanu, Drs. F. F. J. M. Pieters and Dr. D. L. Danielopol for critically reviewing the manuscript. Dr. P. Wagenaar Hummelinck, Dr. L. Botosaneanu, Dr. T. Orghidan and Dr. Cl. Delamare Deboutteville are thanked for placing their samples at our disposal, directly or indirectly. Prof. Dr. J. H. Stock is thanked for the coordination of this project. Mr. J. Zaagman kindly helped with the "finishing touch" of the figures.

This study has been financed by the Netherlands Foundation for the Advancement of Tropical Research (WOTRO), The Hague. The fieldwork of the Amsterdam Expeditions has been supported by grants from WOTRO, the Beijerinck-Popping Fonds (Amsterdam), the Treub Maatschappij (Utrecht), the Amsterdamse Universiteits Vereniging (Amsterdam), and the Fonds Landbouwhogeschool (Wageningen).

Logistic support is acknowledged of the Fundación La Salle (Caracas), the Sociedad Venezolana de Ciencias Naturales (Caracas), and the management of its Estación Biologica (Calabozo), and H. M. Embassy of the Netherlands (Caracas).

\section{REFERENCES}

Botosaneanu, L., 1970. L'Expédition biospéologique à Cuba (mars-juin 1969), organisée par les Académies des Sciences de Cuba et de Roumanie: Présentation sommaire des stations explorées pour le prélèvement d'échantillons de faune aquatique souterraine. Trav. Inst. Spéol. Emile Racovitza, 9: 81-95.

Bronstein, Z. S., 1947. Faune de l'URSS. Crustacés II (1). Ostracodes des eaux douces. Fauna SSSR, (N.S.) 31: 1-334, pls. I-XIV (in Russian).

Broodbakker, N. W., 1982. The genus Heterocypris (Crustacea, Ostracoda) in the West Indies. Part I. Taxonomic characters. Bijdr. Dierk., 52(2): 207-227.

- , 1983a. The genus Heterocypris (Crustacea, Ostracoda) in the West Indies. Part II. Carapace 
length, ecology and zoogeography. Bijdr. Dierk., 53 (1): 115-134.

- $1983 \mathrm{~b}$. The genus Hemicypris (Crustacea, Ostracoda) in the West Indies. Bijdr. Dierk., 53 (1): 135-157.

- $1983 \mathrm{c}$. The genus Strandesia and other Cypricercini (Crustacea, Ostracoda) in the West Indies. Part I. Taxonomy. Bijdr. Dierk., 53 (2): 327-368.

Broodbakker, N. W. \& D. L. Danielopol, 1982. The chaetotaxy of Cypridacea (Crustacea, Ostracoda) limbs: proposals for a descriptive model. Bijdr. Dierk., 52 (2): 103-120.

Danielopol, D. L., 1969. Recherches sur la morphologie de l'organe copulateur mâle chez quelques Ostracodes du genre Candona Baird (Fam. Cyprididae Baird). In: J. W. Neale ed., The taxonomy, morphology and ecology of recent Ostracoda: 136-163 (Oliver \& Boyd Ltd., Edinburgh).

- - 1972. Sur la présence de Thaumatocypris orghidani n. sp. (Ostracoda, Myodocopida) dans une grotte de Cuba. C. r. hebd. Séanc. Acad. Sci, , Paris, (D) 247: 1390-1393.

- , 1975. Remarques sur la diversification morphologique de trois nouvelles espèces d'Elpidium (Ostracoda) à Cuba. Bull. Am. Paleont., 65 (282): 47-60.

-_, 1978. Über Herkunft und Morphologie der Süsswasser-hypogäischen Candoninae (Crustacea, Ostracoda). Sber. öst. Akad. Wiss., math.-naturw. Kl., (I) 187 (1-5): 1-162.

-, 1980 a. Sur la biologie de quelques Ostracodes Candoninae épigés et hypogés d'Europe. Bull. Mus. natn. Hist. nat. Paris, (4) (A, Zool.) 2 (2): 471-506.

,$-- 1980 \mathrm{~b}$. On the carapace shape of some European freshwater interstitial Candoninae (Ostracoda). Proc. biol. Soc. Wash., 93 (3): 742-756.

- , 1982a. The preparation of ostracod limbs, for optical microscopy (dissection, staining and mounting procedures). In: R. F. MAdDocks ed., Eighth International Symposium on Ostracoda, July 26-29, 1982. Programs and abstracts: 41-43 (Department of Geosciences, University of Houston, Texas).

- , 1982b. Nouvelles données sur les Candoninae (Ostracoda) hypogés de Roumanie et Yougoslavie. Bull. Mus. natn. Hist. nat. Paris, (4) (A, Zool.), 4 (3-4): 369-396.

- , 1982c. Deux espèces hypogées du genre Candonopsis (Ostracoda, Candoninae) du sud de la France et de Cuba. Vie Milieu, 30 (3-4) “1980”: 315-323.

Delorme, L. D. \& D. Donald, 1969. Torpidity of freshwater ostracods. Can. J. Zool., 47 (5): 997-999, pl. I.

Furtos, N. C., 1933. The Ostracoda of Ohio. Bull. Ohio Biol. Surv., 5(6): 413-524, pls. I-XVI.

- , 1936. Fresh-water Ostracoda from Florida and North Carolina. Am. Midl. Nat., 17: 491-522.
Hummelinck, P. WagenaAr, 1940a. General information. Stud. Fauna Curaçao, 1 (1): 1-58.

,$-- 1940 \mathrm{~b}$. Descriptions of the localities. Stud. Fauna Curaçao, 2 (4): 1-42.

- , 1953. Description of new localities. Stud. Fauna Curaçao, 4 (17): 1-108.

- , 1981. Land and fresh-water localities. Stud. Fauna Curaçao, 63 (192): 1-133, pls. I-IL.

KanEShiro, K. Y., 1983. Sexual selection and direction of evolution in the biosystematics of Hawaiian Drosophilidae. A. Rev. Ent., 28: 161-178.

Kaufmann, A., 1900. Zur Systematik der Cypriden. Mitt. Naturf. Ges. Bern, 1900: 103-109.

KLIE, W., 1931. Campagne spéologique de C. Bolivar et R. Jeannel dans l'Amérique du Nord (1928) 3. Crustacés Ostracodes. Archs. Zool. exp. gén., 71: 333-344.

- , 1932. Die Ostracoden der Deutschen Limnologischen Sunda-Expedition. Arch. Hydrobiol., Suppl. 11 ("Tropische Binnengewässer III"): 447502, pls. LXIV-LXIX.

- , 1938. Ostracoden aus dem Grundwasser der oberrheinischen Tiefebene. Arch. Naturgesch., (N.F.) 7 (1): 1-28.

Lieshout, S. E. N. VAN, 1983. Calabozoidea, a new suborder of stygobiont Isopoda, discovered in Venezuela. Bijdr. Dierk., 53 (1): 165-177.

Mazepova, G. F., 1976. A new genus of Ostracoda from the fauna of Lake Baikal, and its relationship with the cave-dwelling Candona taurica Schorn. from the Crimea. Trudy limnol. Inst., 18 (38): 54-79 (in Russian).

McLay, C. L., 1978. Comparative observations on the ecology of four species of ostracods living in a temporary freshwater puddle. Can. J. Zool., 56 (4): 663-675.

Métes, G., 1913. Süsswasser-Ostracoden aus Columbien und Argentinien. Mém. Soc. neuchât. Sci. nat., 5: 639-663.

Petkovski, T. K., 1969. Über die Notwendigkeit einer Revision der Süßwasser-Ostracoden Europas. In: J. W. Neale ed., Taxonomy, morphology and ecology of recent Ostracoda: 76-84 (Oliver \& Boyd Ltd., Edinburgh).

Pregill, G. K. S. L. Olson, 1981. Zoogeography of West Indian vertebrates in relation to Pleistocene climatic cycles. A. Rev. Ecol. Syst., 12: 75-98.

Rome, D. R., 1969. Morphologie de l'attache de la furca chez les Cyprididae et son utilisation en systématique. In: J. W. Neale ed., The taxonomy, morphology and ecology of recent Ostracoda: 168-193 (Oliver \& Boyd Ltd., Edinburgh).

SARs, G. O., 1896. On fresh-water Entomostraca from the neighbourhood of Sidney, partly raised from dried mud. Arch. Math. Naturv., 18 (3): 1-81, pls. I-VIII. -, 1901 . Contributions to the knowledge of the fresh- 
water Entomostraca of South America, as shown by artificial hatching from dried material, Part II. Arch. Math. Naturv., 24 (1): 1-52.

SCHÄFER, H. W., 1945. Grundwasser-Ostracoden aus Griechenland. Arch. Hydrobiol., 40 (4): 847-866.

Stock, J. H., 1979. Amsterdam Expeditions to the West Indian Islands, Report 4. Station list. Verslagen technische Gegevens Inst. taxon. Zoöl. (Zoöl. Mus.) Univ. Amsterdam, 20: 1-78.

Tressler, W., 1941. Ostracoda from Puerto Rico bromeliads. J. Wash. Acad. Sci., 31: 263-269.

Triebel, E., 1963. Ostracoden aus dem Sannois und jüngeren Schichten des Mainzer Beckens: Cyprididae. Senckenberg. leth., 44: 157-207.

Received: 1 July 1983 